\title{
The Killing Fields of South Africa: Eco-Wars, Species Apartheid, and Toal Liberation
}

\author{
Steve Best
}

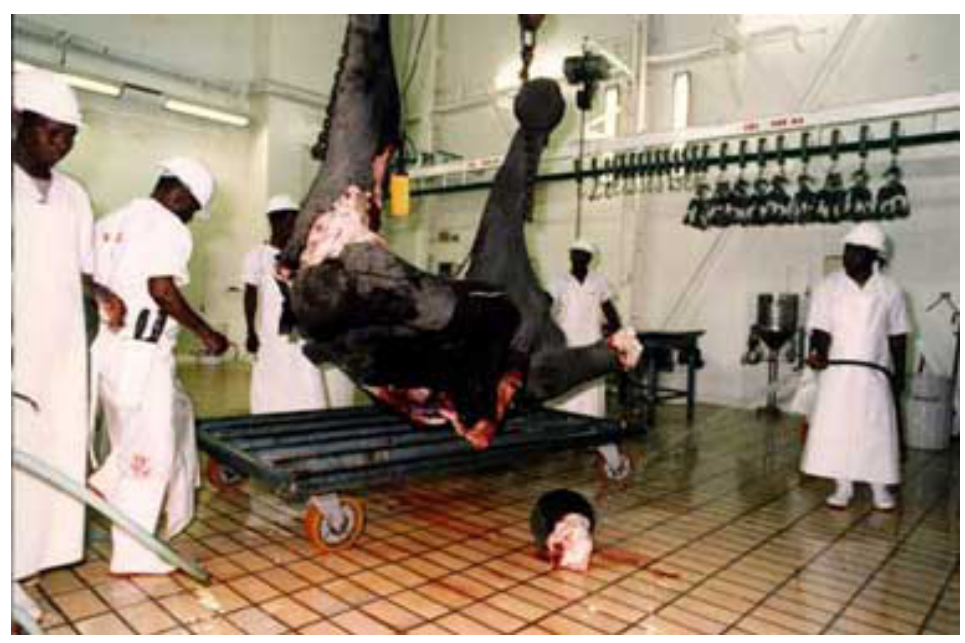

photo by Michele Pickover

In South Africa, the elephant has emerged at the center of heated political debates and culture wars, as the government and national park system maneuvers to return to the practice of "culling"- a hideous euphemism for mass murder of elephants.[2] Culling advocates—including government officials, park service bureaucrats, ecologists, "conservationists," large environmental organizations such as the World Wildlife Fund, farmers, and villagers - argue that elephants have had deleterious effects on habitat and biodiversity and their herds need to be "managed" and reduced. Farmers and villagers complain that elephants are breaking reserve fences, destroying their crops, competing with their livestock for food, endangering physical safety and sometimes attacking and killing humans. The consensus among these parties is that biodiversity, ecological balance, and human interests trump the lives and interests of elephants, and that the most efficient solution to the "elephant problem" is the final solution of culling thousands of lives.

Opponents of culling include animal activists in South Africa and the world at large, ecologists, and thousands of Western tourists fond of elephants and the desire to see them in their natural habitat. In addition to the moral argument that elephants have intrinsic value and the right to exist—quite independent of their utility for humans- 
critics dismiss the claim that elephants threaten habitats and biodiversity. They emphasize that numerous alternatives to controlling elephant populations other than gunning them down exist, such as contraceptives and creating corridors between parks to allow more even population distribution. Against hunters and villagers alike, many culling opponents argue that elephants are worth much more alive than dead, and that elephants and humans alike win by developing the potential of ecotourism. The ethically and scientifically correct policies are not being adopted, critics argue, because government and "conservationists" are allied with the gaming, hunting, and ivory industries, and all favor a "quick fix" over a real solution. Animal advocates worry that the resumption of culling will reopen the global trade of ivory and argue that the ivory industry is driving this policy change.

This essay supports the rights of elephants to live and thrive in suitable natural environments and opposes all justifications for culling elephants and exploiting African wildlife in general.[3] My purview is much broader than elephants, hunting, and the ivory trade, however, as I see the human-elephant "conflict" as a microcosm of the global social and ecological crisis that involves phenomena such as transnational corporate power, state totalitarianism, militarism, chronic conflict and warfare, terrorism, global warming, species extinction, air and water pollution, and resource scarcity. The approach of the South African government and people toward the "elephant problem" has global significance and is an indicator of whether or not humankind as a whole can steer itself away from immanent disaster and learn to harmonize its existence with the natural world.

I first analyze the influence of the hunting, gaming, and ivory industries, and expose the profit motive driving their illicit production and trade. I then compare the regimes of social apartheid (white exploitation and domination of blacks) to the much larger system of species apartheid (human exploitation and domination of animals) to highlight the similarities between the regimes of racism and speciesism, and to stress the superficiality of the changes that culminated in the abolition of institutionalized racism while leaving intact species apartheid and that challenged white supremacy but not human supremacy.[4] I then show how euphemisms such as "culling" and "sustainable use" are transparent covers for violence and exploitation and stem from neo-Malthusian and eco-fascist mindsets. Put bluntly, I argue that South African "conservation" policies are akin to (certainly not identical with in all respects) Nazism in the vilification of the animal Other, the scapegoating of elephants as causes rather than effects of environmental problems, the bureaucratic language and technical administration of mass killing, and the pursuit of a final solution to the alleged problem of elephant overpopulation.

More generally, I argue that human beings worldwide urgently need a paradigm shift in the way they frame their relationships with animals, a conceptual revolution that abandons the dominator psychologies, hierarchical worldviews, and exploitative practices (forged some ten thousand years ago with the emergence of agricultural society) in favor of a new ethics promoting nonviolence, respect for all sentient life, and the harmonization of the social world with the natural world. My approach is rooted in a critical social theory and radical politics that explores the connections between social and environmental problems, relates them to the emergence of hierarchical mentalities and social forms, and argues that the solutions to crises in both realms requires revolution social change that seeks to dismantle the inherently exploitative and unsustainable system of global capitalism while rebuilding societies along decentralized and democratic lines. In contrast to other critical approaches, however, my orientation jettisons the speciesist baggage of humanist, Leftist, and so-called "revolutionary" or "progressive" outlooks in order to link radical social theory to animal rights and thereby significantly expand the critique of hierarchy and broaden the composition of contemporary resistance movements. Given that the goals of the human, animal, and earth liberation movements are inseparably intertwined, we need a global alliance politics of unprecedented scope and range, one that pursues the goal of total liberation.

\title{
Big Game, Big Business
}

\author{
"If monetary value is attached to something it will be exploited until it's gone. That's what happens when you convert \\ living beings to cash. That conversion, from living forests to lumber, schools of cod to fish sticks, and onward to numbers \\ on a ledger, is the central process of our economic system." \\ -Derrick Jensen
}

South Africa is known to the world not only for its magnificent wildlife and parks, but also for the trafficking in endangered species, the huge gaming and hunting industries, and the brutal killing of elephants for ivory and body parts.[5] Virtually lawless in its regulation of the animal trade, South Africa has the highest species extinction rate of 
any area on the planet, for big game is big business and money and resources are all that count. One of the richest "resources" in South Africa's possession is the wildlife that roams the plains. Yet, rather than respecting the intrinsic value and rights of animals, or even adopting the "enlightened anthropocentric" policy of "ecotourism" (see below), South Africa has chosen to auction wild animals such as elephants and lions to the highest bidder. The "sustainable use" policy of South Africa is an unsustainable farce.

Every year, tens of thousands of animals are killed with impunity in South Africa for the trivial purpose of “sport." For a handsome fee of $\$ 20,000$ to $\$ 50,000$, tourists (such as stream in from Japan, the United States, and Europe) can shoot about any species they want.[6] Most notoriously, lions and other animals are killed in "canned hunts" that confine animals (often domesticated and semi-drugged) within fenced enclosures. The outcome is guaranteed, and the mighty warriors go home with a trophy to mount on the wall or decorate the floor. Whereas wildlife sanctuaries are banned in eight of South Africa's nine provinces, all provinces fully sanction captive-breeding and hunting ranches. Currently, there are 9,000 privately owned ranches that employ 70,000 people who cater to the wants of foreign hunters in search of big game.[7]

A dramatic indication of the bloodshed in the killing fields of Africa is the systematic pogrom against elephants, a species comprised of the largest land mammals on earth and renown for its intellectual, emotional, and social complexity. In 1930, Africa was home to a lush population of 5-10 million elephants. Beginning in the 1960s, however, poachers and armies waged a vicious war of extermination against elephants, reducing their numbers to 1.3 million by 1979. Between 1970 and 1989, another million elephants were slaughtered for their ivory tusks. In 1989, the Convention on International Trade in Endangered Species (CITES) passed a global ban on ivory. Due to intense international pressure and threat of a tourism boycott, South Africa declared a moratorium on culling in 1995. These measures helped to reduce elephant poaching, but illegal poaching and ivory trading still flourish. Today, only 600,000 elephants survive in the South African wild.

Perversely, species are valued-economically, not ecologically — to the degree that they are endangered.[8] They are more important dead than alive. The only way an ivory hawker can collect his "white gold" is through the death of an elephant. Able to gather a large sum of money on the international ivory market, which continues to thrive despite a 1989 international ban against its trading, the lure of money is irresistibly seductive for poachers.[9] In the vast and burgeoning international trade in wild animals and plants—as advertised and mass marketed to a global clientele through web sites and magazines-South Africa is the biggest wildlife trader on the continent. Like the lawless days of the Old West in the United States, the South African government and conservation organizations operate in an anarchistic environment, flouting the national and international laws that-feebly-regulate the trafficking in animals and endangered species. Governments, conservation organizations, tourist offices, the Department of Environmental Affairs and Tourism, and all provinces enable and support the gaming, hunting, and ivory industries that kill tens of thousands of animals each year for "sport" and profit.

In South Africa, as throughout the continent, the park system and state operate within a global capitalist marketplace where the name of the game is growth, profit, and conformity to demands of neoliberalism and transnational corporate domination via resource extraction, debt imposition, and "structural adjustment" programs that minimize regulations, lower wages, privatize social sectors, and control resistance.[10] To survive in the brutal and nihilistic system of global capitalism, the state commandeers what its best assets-wildlife and natural environments - to dole them to industries and private interests. The illegal wildlife trade is estimated to fetch $\$ 6-20$ billion a year. Needless to say, the interests of animals, the environment, communities, and future generations never enter into the economic calculus of state elites and Western CEOs. The goal of the new South African National Park (SANP) management policy is increased trading of animals on the world market, while displaying complete indifference as to whether they end up in a city or roadside zoo, a circus, a laboratory, or a slaughterhouse. In the words of a one Park Minister (a term that ironically implies ethical stewardship of animals and nature), "I see no reason why we shouldn't be able to make an income out of these [parks].”[11]

If a park profits from animals and land, and puts the money back into sound care and management, it is difficult to object to this pragmatic speciesism given state budget constraints and the realities of global capitalist economies. But "responsible stewardship" is hardly the hallmark of the SANP staff who regard animals as commodities and dispensable resources to be sold to the highest bidder and obligingly play their own critical part in the corporate pillage of the planet. Parks and animals, like everything else, are viewed in the basest terms possible, as nothing but commodities that if lacking in economic value have no value at all.[12] 


\section{| Species Apartheid}

"A new society cannot be created by reproducing the repugnant past, however refined or enticingly repackaged."

South Africa inherited and maintained an ugly legacy of violence and domination from European colonialists, a system of exploiting humans and nature, racism, and discrimination. In 1948, Dutch Afrikaners referred to this social structure they received and developed as "apartheid" (which literally means "separate state").

Apartheid was a brutal system of class and racial domination maintained by repression, violence, and terror, whereby a minority of wealthy and powerful white elites exploited and ruled over the black majority. Apartheid was a conceptual and ideological system, whereby white elites positioned themselves as superior in relation to the black masses they branded as inferior, and an institutional system, which exploited black labor power, stripped them of basic rights, and strictly segregated the races. Whites declared blacks noncitizens, and confined them to different beaches, hospitals, schools, churches, theatres, restrooms, trains, buses, and other public areas. The respective sexes too were kept apart, as interracial sex and marriage was illegal.

Reviled throughout the world, pressured economically, and attacked at every point by the black resistance movement, the apartheid system began to fall. Nelson Mandela, imprisoned on Robben Island for 27 years, was set free in February 1990, and apartheid was dismantled in 1994. South Africa's first democratic elections were held on April 27, 1994, and Mandela, the leader of the African National Congress (ANC), became the country's first black state president. From May 1994 to June 1999, Mandela presided during the transition from apartheid and minority rule to a fledgling democracy, a system that unfortunately remains plagued by great poverty, unemployment, inequality, and discontent.[13]

Despite the changes that (officially, at least) ending social apartheid, nothing changed in the underlying structure of species apartheid.[14] Just as social apartheid is anchored in white hatred of blacks, so species apartheid stems from human contempt for nonhuman species-such as expressed in the iconic images of joyful hunters powerposing with their "kill." [15] Just as racism arbitrarily defines one group of humans as superior to another, out of sheer prejudice and ignorance, so speciesism position human animals as superior to nonhuman animals, and anoint themselves as the end to which all other life forms are mere means. Whereas the racist mindset roots its hierarchy in skin color, the speciesist mindset devalues and objectifies animals by dichotomizing the evolutionary continuum into human and nonhuman life. As racism stems from a hateful white supremacism, so speciesism draws from a malignant human supremacism, namely, the arrogant belief that humans have a natural or God-given right to use animals for any purpose they devise.

Akin to social apartheid, the conceptual segregation of species apartheid informs an institutional segregation, in which animals are removed from social purview and confined to cramped pens and cages, where their oppression is mainly hidden. As much as possible, South African whites tried to hide black oppression by relegating them to "homelands" and designated public spaces apart from white society. Similarly, while some animals like elephants roam in public parks and are spectacles for eco-tourism, the most vicious forms of exploitation occur in dungeonlike laboratories, factory farms and slaughterhouses in rural outposts, and private hunting enclosures. As South African journalist, Mantsadi Molotlegi, writes in regard to the epiphany that radically changed her worldview, moral compass, and politics, "The way we treat animals has all the hallmarks of apartheid—prejudice, callous disregard for suffering, and a misguided sense of supremacy ... group areas and segregation helped to keep the suffering of black people hidden from view. So too with the animals."[16]

Like racism, speciesism deploys a "Might is Right" philosophy that sees the ability of the powerful to rule over the powerless as its justification for doing so, ignoring the fact that the greater the power the greater the responsibility to use it humanely, democratically and ecologically. Like social apartheid, species apartheid is rooted in the enslavement of beings exploited for profit, as global capitalist markets continue to thrive through extreme exploitation and slavery. Victims of severe oppression, both animals and black Africans were slaves subject to economic exploitation within capitalist systems. Whereas speciesism and racism are pernicious ideologies that underlie animal and black oppression, their subjugation was also informed and determined by capitalist logic and market networks that thrive from slave labor. Speaking of the complex causes of apartheid, an African National Congress (ANC) article states that, "Afrikaner nationalism was [not only about] evicting African blacks simply because of their race; much of it was [about a desire to appropriate land, resources and labour power... it must never be forgotten that Apartheid and racial discrimination in South Africa, like everywhere else, has an aim far more important than discrimination itself: 
the aim is economic exploitation. The root and fruit of apartheid and racial discrimination is profit." [17] As the white South African minority enjoyed the highest standard of living in Africa, on par with many western nations, the black majority were marginalized and impoverished in every area such as income, housing, and schools.

As with blacks toiling in the fields and mines of capitalist, — whether it be horses transporting people and goods in urban cities; or cows, pigs, and chickens confined in stalls, crates, and cages manipulated (including genetically) to produce maximum quantities of meat, milk, and eggs; or mice, rats, rabbits, cats, cogs, and chimpanzees in research laboratories who are artificially sickened and serve as sheer bodies for the production of meaningless quantitative data or to provide organs for human "harvest."

As bad as black Africans had it throughout the era of social apartheid, species apartheid is an even more oppressive system. This is because a significantly greater number of animals (dying by the billions) are killed each year, the methods of exploitation typically are more brutal, and there is far less outcry over their suffering and death. Although blacks were violently repressed and many were beaten, tortured, and killed, they were not bred, farmed, confined, and exploited for hunters to shoot down in a demented drama of "sport" and human mastery of nature. While jailed and beaten, blacks were not captured and sent to laboratories for experimentation, cut into pieces and consumed for meat, nor dismembered and sold for jewelry and paperweights. Although black victims of apartheid were murdered by the thousands, over 40 billion animals die each year at the hands of human oppressors in various systems of exploitation, from slaughterhouses and fur farms to hunting fields and laboratories. While the world conscience was slow to awaken to condemn the exploitation of blacks, they ultimately did and were crucial factors in the abolition of apartheid; the cries against species apartheid, however, are barely audible — those quickly growing. And even those opposed to the trade of ivory and chimpanzee meat condone, approve, and participate in myriad forms of animal exploitation such as meat, dairy, and egg consumption or wearing leather products.

The crucial point here is not to quantify suffering or to privilege one form of oppression over another, but rather to draw parallels among different forms of oppression and to call attention to the plight of animals within global species apartheid systems. In the time span since 1994, with the tripartite alliance of the African National Congress, the Congress of South African Trade Unions, and the South African Communist Party, a democratization process has begun to improve life for human beings. But absolutely nothing has been done to ameliorate the slaughter and suffering of animals. In post-apartheid South Africa, one finds the same pseudo-"park" and "conservation" policies, the same cronyism and corruption, the same morass of legal codes and lack of regulation, the same systematic violation of treaties such as CITES, and the same arrogant and violent speciesism that deems animals beings and uses force and aggression to unconscionably exploit them for human purposes.

To be completely accurate, in post-apartheid South Africa the killing rates have accelerated, as exploiters have escalated their extermination campaign against elephants, chimpanzees, gorillas, tigers, and other species. This wholesale massacre of animals — as aggressive, hateful, violent, and bloody as any genocidal rage Africans have unleashed on each other in Rwanda, Darfur, and elsewhere-is driving many species to extinction, while destroying habitats and upsetting ecological balance. As elsewhere in the crumbling human empire, animals in the African wild are under siege, whether it be chimpanzees stolen from the jungles to die in Mengelesque research laboratories or the lions and cougars mowed down by demented hunters. Soldiers in Rwanda have used endangered mountain gorillas for target practice. Paramilitary poachers have sprayed bullets from semi-automatic weapons into terrified herds of elephants mowed down to their death.[18] Rebels assisted by the South African Defense Force killed 60,000 elephants to finance their war in Angola.[19] In 2005, Robert Mugabe, President of Zimbabwe, ordered the slaughter of ten elephants to serve barbecued pachyderm at festivities marking the twenty-fifth anniversary of Zimbabwe's independence and black rule.

How can one expect peace, tolerance, community, and democracy in a country where such pathological violence is unleashed routinely on animals? Does not African exploitation of animals manifest and perpetuate the worst aspects of colonial rule over Africans? Doesn't the dominator mindset and cycle of violence have to be broken at every point?

\section{| The Pathology of Humanism}

“This hell made mockery of all blather about humanism." -Isaac Bashevis Singer 


\footnotetext{
"The assumption that animals are without rights, and the illusion that our treatment of them has no moral significance, is a positively outrageous example of Western crudity and barbarity. Universal compassion is the only guarantee of morality."
}

Where humans fail to make the most profound changes - those involving their relationship to the vast living earth-political regime changes mean nothing to animals and perpetuate violence and social and ecological crises. For whether a regime is Left or Right, Capitalist or Communist, White or Black, Afrikaner or ANC, the same species apartheid mentality and brutal policies prevail. Animals are still exploited as slaves; they are still reduced to resources for human use, and they still suffer and die in unimaginable numbers.[20]

Under the pseudo-progressive guise of progress, rights, democracy, and equality, leftists, communists, democratic humanists, black nationalists, and community activists murder animals no different than white, racist, Western, capitalist, imperialists. Consider, for instance, the Zimbabwe "Campfire Conservation Association" that lobbies the U.S. Congress for funds to kill elephants for community benefit. Through a blatant discourse of objectification, Campfire member Stephen Kasere unashamedly reveals his speciesist outlook: "We just want the elephant to be an economic commodity that can sustain itself because of the return it generates. Ivory is a product that should be treated like any other product.”[21]

This is reification - the reduction of a living subject to the status of a thing-in its finest form; it is a hateful, discriminatory, ignorant, morally repugnant outlook that fails to understand the difference between an elephant and an eggplant. Ivory, in fact, should not be treated like "any other product" as this "product" comes from a complex living being murdered for its body parts.[22]

To provide another example of the speciesist and objectifying views informing radical, humanist, and communitarian activists, consider James Shikwati's article, “Conservation Effort: Protecting Africa's People and Wildlife."[23] Shikwati describes the plight of Kenyan villagers who receive little or no benefits from wildlife tourism, as profits are siphoned into private hands and Western banks. He proposes that if elephants belonged to communities, poaching would be reduced as people are not likely to destroy their own "property" or steal "value" from themselves. This is a sensible search for an economy that benefits both humans and animals, replacing a zerosum game with a win-win situation, but Shikwati frames elephants objects, not subjects, as mere resources that exist not for their own purposes but rather for the benefit of humans. Broadening the capitalist language of objectification and commodification used by hunters and so-called conservationists to grant ownership rights to communities and not only individuals, Shikwati urges us to view a national park as a "village bank" where animals are the peoples' "assets."

From his communitarian-capitalist perspective, Shikwati argues that "there is nothing immoral in having people own wildlife. It is immoral to have them trampled to death [be elephants] and their crops destroyed with no gain in sight." In fact, there is something wrong-profoundly wrong-about ownership of wildlife. It involves a reduction of animals to the status of property, things, commodities, and slaves; it causes, promotes, and legitimates insensitivity to their pain, suffering, and true nature. It is both a philosophical and moral failing. It is the Lockean ownership and property rights mentality that grants exploiters the legal authority to torture and kill other species in any way they see fit, and, conversely, that makes property destruction and economic sabotage for the cause of animal liberation serious crimes.[24] The crass commerce language of "resources" and "assets" is one thing when it refers to oil, gas, or corn crops, and quite another when used to frame the lives of sentient beings as things.

The gaming, hunting, and ivory industries see animals in the same capitalist and utilitarian terms as Kasere and Shikwati. Voices of the people, they make the same appeal to animals as their property over which humans exercise powers of life and death rights as a King commands his subjects. They urge respect and equality for humans, while evincing no understanding or sympathy for animals. They appeal to democratic values while engaging in totalitarian behaviors. The extent of Kasere and Shikwati's moral objection to the assault on animals, biodiversity, and evolution itself is to demand a bigger piece of the pie to distribute among more people, without seeing how the "pie" itself, however carved up and doled out, is the product of violence and exploitation.

While Shikwati rightly criticizes the Kenyan government for indifference to its people, he shows the same apathy to animals in his quest to democratize the killing (its benefits and to some degree its acts) of wildlife rather than to abolish killing altogether and organize alternative-nonviolent and nonexploitative-sources of community income. He understandably expresses loss over people killed by wildlife, but shows no sorrow for millions of animals shot down on the African plains. When Shikwati and others, such as the director of the WWF in Namibia, speak enthusiastically of the economic benefits of killing elephants for human communities, they ignore the inestimable 
value living elephants have to their families and communities

Quite reasonably, Shikwati argues that "the poor populations of the world must make a living from their natural surroundings ... [o]therwise they will have little incentive to preserve these surroundings, including the wildlife that inhabits them." Given that they kill wildlife to survive, and not for sport or profit, he bristles at animal rights critiques and denounces them as arrogant, Eurocentric, and elitist. "Only people who do not make a living in the vicinity of the wildlife reserves have the luxury of questioning whether or not human beings have the right to control wild animals." [25]

Like Nazi ideologues, totalitarians, and dogmatic fundamentalists of all stripes, Shikwati precludes criticism from outside his culture, constructing a binary opposition in which Western critiques of African cultures are always wrong and indigenous peoples' defense of their traditions and lifeways are always right. Yet, betraying the fallacy of cultural relativism, the same logic can be used by Western imperialists (e.g., through the gospel of Progress that equates social advance with economic growth) to disable anticolonialist critiques of their exploitation and looting of the Southern hemisphere. Hiding under the cover of cultural relativism, Kasere and Shikwati provide carte blanche license for African communities to treat animals in any way that advances their needs and interests.

But there is no guarantee that villagers — often as anthropocentric and cruel as anyone else-would treat animals with more respect than big government, corrupt state elites, exploitative industries, and co-opted "conservation" organizations. Where sensitivities are lacking, however, economics and self-interest can dictate "humane treatment." Poaching and trafficking in endangered species may indeed be reduced where democratic communities manage and protect the precious "assets" in their "bank," as opposed to the reckless and unsustainable practices of outside corporate and hunting interests.

But, to underscore the fundamental point, if animals have basic rights to life and liberty-a question that dogmatic humanists dismiss, dodge, and rarely seriously or intelligently engage-these rights are inviolable and thereby trump human utilitarian considerations.[26] As emphasized by Kant's universal moral imperatives, to treat another as an end rather than a means demands we accord them respect, principles which and and should be extended to govern human relations to animals.

At this point, inevitably, humanists, "progressives," and indigenous voices dredge up the tired ad hominem slander that animal rights—-typically Western, white, and economically "privileged"-are elitists who disrespect traditions and impose values relevant to conditions of material privilege but not to the realities scarcity and poverty. To be perfectly clear: there is nothing inherently racist or elitist about "white privileged westerners" (such as myself) criticizing other cultures on moral grounds, as if non-Western cultures are morally perfect, beyond reproach, and completely consistent in their condemnations of the West. U.S. systems of factory farming, Japanese whaling and dolphin slaughter, Canadian seal hunts, and South African elephant culling are all morally reprehensible, and can be judged as such from the ethical and logical foundations rooted in the rigorously argued case for animal rights.

Indeed, we cannot pass over the irony, inconsistency, and hypocrisy of non-Western condemnation of animal rights as an elitist, white, Western, privileged discourse, while the conceptualization of animals as resources, bank reserves, and community property stem from Western (capitalist and individualist) concepts of ownership and property rights. Attacks on animals rights from an indigenous and communitarian standpoint are framed in the corrupt capitalist language of commodification and property rights, whereas animal rights rejects the idea that animals are property, whether of individuals or communities. Whereas indigenous critiques are rooted in Western capitalist concept, animal rights is a profound break from the entire Western tradition what defines humans as superior to animals by virtue of their rational and logical abilities.

Cruelty is cruelty, and violent and exploitative attitudes and practices can and should be condemned universally; chicanery, dogmatism, and hiding behind the cover of cultural relativism must be exposed and rejected, as critical theorists give due attention to nuances such as arise in the hunting practices of "subsistence cultures." The normative thrust of animal rights assails animal exploitation of any kind, regardless of the oppressor's race, class, gender, religion, or nationality. Animal rights theorists typically distinguish between animal exploitation and subsistence killing; all condemn the former and many condone the latter as morally defensible given survival needs. But animal rights advocates also point out that genuine subsistence cultures (such as many wrongly include the Intuits in this category) are rare or nonexistent, and "subsistence cultures" such as the Makah Indians in the U.S. Northwest kill whales with speed boats and high-powered spear guns, and have been seen to disrespectfully dance on their dead bodies in a ritual of domination rather than respect. [27]

The animal rights standpoint urges all cultures to relate to animals in nonobjectifying, nonviolent, and respectful ways. It is a moral revolution that has moved beyond Western states to take root throughout the globe and thus is 
influential in nations and cultures such as Taiwan, Russian, and South Africa itself. The ad hominem denunciations of animal rights as Western and elitist have been refuted by a rapidly growing global movement to protect all innocents, end all exploitation, eradicate all prejudice, and stop all violence. Charges of racism and elitism are all the more erroneous and divisive where animal advocates stand in solidarity with oppressed peoples and try to establish interconnections that exist among movements for human, animal, and earth liberation in ways that deepen and strengthen each crucial element of a needed total revolution (see below).

Thus, when Nelson Mandela rails against racism, saying "I detest racialism, because I regard it as a barbaric thing, whether it comes from a black man or a white man," we must expand his objective standard of justice and moral accountability to a include a diatribe against speciesism. To deepen Mandela's moral truth by way of paraphrase, the holistic voice of conscience today would cry out: "I detest speciesism, because I regard it as a barbaric thing, whether it comes from a black person or a white person."

\section{| Pseudo-Conservation and the Linguistic Sanitization of Violence}

"In our time, political speech and writing are largely the defense of the indefensible." -George Orwell

There is much talk in South Africa of the "conflict" between - one that demonizes elephants as predators rather than prey, one that is informed by a primitive "Might is Right" ideology and is resolved by violent methods, one where elephants always lose. In contrapuntal chorus, conservationists, farmers, hunters, and villagers decry the "severe ecological damage" allegedly caused by elephant overpopulation in some areas and argue that elephants are harming plant life, endangering biodiversity, and "gobbling up" crops with their voracious appetites, bulldozing bodies, and burgeoning numbers.[28] Rather than look deeply into the ultimate causes of ecological imbalance, elephobes advocate killing as the "solution" to the "elephant problem."

Instead of confronting systematic violence against animals as a profound problem with enormous implications for humans themselves, the brutality of species apartheid is linguistically sanitized in discourse such as "culling," "sustainable use," "sustainable off take," "humane use," "harvestable resource," "adaptive management," and "population management." As noted above, so-called "conservationists" and, indeed, alleged "true environmentalists," refer to elephants as "renewable natural resources" as if they were things. [29] Here is a typical gem from the mouths of conservationists that reifies complex social beings as sheer things, resources, and commodities: "The elephant is a natural resource with assignable ownership. Foreign hunters are willing to convert that from an asset to capital in exchange for a cultural experience compatible with the history and use of the elephant." Exchanging moral discourse of the language of the stock market, this view reduces the elephant to sheer commodity status, denying it any fundamental right to life, as it sanctifies the hunter as a property owner, a vital trader in the global exchange market, and a sophisticated seeker of "cultural experience." [30]

Conservationists define the "culling" of elephants as "the managed alteration of a game populations numbers or compositions, when at odds with its resources, health and welfare, or man's interest."'[31] Obscene abstractions such as the "management of elephant density" obscure the very concrete act of killing elephants by shooting them with tranquilizing darts from helicopters, allowing them to slowly and painfully suffocate and die, finishing off those still alive with a bullet to the head or a blade to their throat, and then dismembering and exploiting every penny's worth from their mutilated bodies.[32] Once one clears the fog of semantic chicanery, moral posturing, and allegedly sound and objective science, it is clear that culling is a demonization and slaughter of the innocent. It stems from the human hatred of animals, from the proclivity to annihilate anything that threatens our selfish individual, groups, or species interests, and from the insatiable and inveterate appetite for exploiting life and resources for profit. Culling spreads terror from air and land, breaks apart families, and causes acute distress among herds near and far (who can hear and sense the fear, panic, and slaughter of their fellow beings). Culling is a form of ethnic (or species) cleansing where victims are targeted because they are deemed inferior beings, problems or threats to the interests of the superior group, and thus relegated to the category of the Other to justify mass slaughter.

The Orwellian mystifications rampant throughout so-called conservationist and scientific discourse evoke other nefarious speciesist classics, such as the "humane treatment" of animals in the cages of laboratories, circuses, fur farms, breeders, factory farms, and slaughterhouses, or, best of all, "humane killing" — as if there is a "humane" way 
to strip intelligent and sensitive beings from their natural kind and world, to confine them in cramped cages and stalls, to deprive them of their life instincts, to drive them mad or morbidly depressed, and to violently kill them with a blade or knife as they shriek in fear and often are conscious during the act of dismemberment.

Some groups have taken initiatives — albeit from a speciesist perspective coached in the language of reificationto promote "sustainable" elephant hunting. In African countries such as Namibia, the World Wildlife Fund claims to be successfully teaching rural communities how to prosper through "sustainable natural resource management," which includes "sale of thatching grass and crafts, tourist concessions, and revenues from trophy hunting" (my emphasis).[33] Working with government and teachers to implement new curricula, the ultimate goal of their Environmental Education program is "to provide the knowledge to use natural resources with an eye to the future. Planting trees for fuel and timber, preventing water-borne and other diseases, countering soil erosion and pollution, and tapping into indigenous knowledge to maintain a healthy environment." [34] In a qualitative leap beyond this speciesist approach that exploits elephants for human resources and perpetuates instrumentalist and exploitative worldview underpinning the social and ecological crises afflicting the globe, another group provided poachers not with money derived from the slaughter of innocents but rather with alternative livelihoods by training them to become carpenters and involving them in a village sewing cooperative they launched.[35]

Key to the worldview of cunning conservationists and planetary pirates running amuck on land and sea is the concept of "sustainable use." Apart from its semantic deformation, the phrase implies ecological sensibility, benign stewardship, and moral responsibility in awareness of the need to consume "resources" within ecological limits, and not take more than can be replaced and renewable by future generations. The profit-driven, crassly anthropocentric utilitarian model of "sustainable use," however, is a disingenuous device deployed to distract attention from attitudes bereft of holistic attitudes and actions that are entirely unsustainable.

The discourse of "sustainable use" is prostituted and misshaped because the global, voracious demand for transforming beautiful, biologically important, often endangered animals into bloody carcasses increasingly outstrips the supply. [36] According to Michele Pickover, "South Africa has the highest estimated rate of extinctions for any area of the world, with 37 per cent of its mammal species threatened.' [37] The hunting and gaming industries follow not the credo of "sustainable use," but rather the imperative to exploit, kill, and plunder as much as possible, as quickly as feasible, and for maximum profit and gain. The exploitative and utilitarian outlook of "sustainable use" precludes any truly sustainable mode of human existence and harmony with nature, and the contradiction can only be resolved-beyond dismantling markets and profit imperatives that drive exploitation-through a conceptual gestalt shift that fosters connectedness to the world and appreciation of the inherent worth of other species.

The "scientific management" of parks obfuscates the economic and political interests that shape "conservation" policies. In the United States, federal regulatory agencies such as the United States Department of Agriculture (USDA) and the Food and Drug Administration (FDA) allegedly protect the welfare of animals and citizens, but in fact promote the agendas of meat, dairy, and pharmaceutical industries. Similarly, South African "conservation" organizations supposedly act in the interests of animals, but in truth advance the deadly agenda of hunting and gaming industries. As one writer observes, the conservation system "was conceived during apartheid and reflected the authoritarian norms of that era. Today, conservation boards remain under the control of long-entrenched bureaucrats. Mostly white, Afrikaans-speaking men, these functionaries come from the same tight-knit community as many of those involved in captive breeding and canned hunting. Many are hunters themselves." [38]

Westerners would be astonished to realize the degree to which African "wildlife management" is a deceptive and fraudulent charade. Quite commonly, animals are not protected in the park system, but rather are temporarily stored there as resources for future use. The SANP system has a long history of supplying animals such as rhinoceros, elephants, and lions to private landowners and hunting operators. "Conservation" organizations, moreover, are fronts for animal exploiters. With the state and animal exploiters, "conservationists" advocate "sustainable use" policies that appear to be responsible "environmental management," but in reality mask unsustainable levels of killing that are driving numerous species to the brink of extinction. Perhaps most of all, U.S. citizens would be outraged to learn that millions of their tax dollars subsidize elephant killing through Congressional funding of South African hunting lobbies.[39]

It is a perversion of the concept of "conservation" when its semantic range extends to taking not preserving life, to driving species extinction rather than promoting species preservation. Of course, "conservation" is part of a larger ecological vocabulary, one that values ecosystems over individual animal lives. Thus, from this type of holistic outlook that favors systems over individuals, hunting and fishing are perfectly acceptable pastimes, "sports," 
traditions, or businesses_-so long as, according to the standard proviso, the one pulling the trigger or yanking the hook understands and respects ecological balance and sustainability requirements. From this perspective, it follows that the life of an individual elephant, lion, rhinoceros, or chimpanzee has no innate or important value, for when "harvested properly, animals are replaceable "resources."

Environmentalists, ecologists, and conservationists are notorious for their partial understanding of the big picture, their commonplace embrace of meat-eating, and their defense of hunting and other exploitative practices. Proponents of "green" lifeways view animals as species, not individuals, and embrace the speciesist ideology that frames them as resources for human use. Like everyone else, they mouth vague platitudes that endorse animal welfare views that merely reinforce speciesism and legitimate every imaginable form of cruelty, for welfarist views seek bigger cages not empty cages and the "humane treatment" of animal slaves rather than the abolition of animal exploitation.

\section{| Malthus, Resource Wars, and Eco-Fascism} "In their behavior toward creatures, all men were Nazis. The smugness with which man could do with other species as he
pleased exemplified the most extreme racist theories, the principle that might is right."
-Isaac Bashevis Singer

Intoxicated with the promise of reason, science, and technology, preaching a new gospel of Progress, many Enlightenment thinkers of the eighteenth century believed that the laws of history were inevitably leading to a universal community governed by reason, where all humanity would be happy and free. A writer by the name of Thomas Malthus, however, observed a fatal flaw in this utopian scenario, insofar is it ignored basic laws of ecology and was rooted in the modernist fallacy of nature as a cornucopia of inexhaustible resources. In his book An Essay on the Principle of Population (1798), Malthus analyzed a dynamic where human populations grow at a geometric rate $(1,2,4,8,16 \ldots)$, whereas food supplies increase only at an arithmetic rate (1, 2, 3, 4...).[40] Eventually, humans overshoot available resources and encounter conditions of scarcity. One way or the other, Malthus reasoned, human populations will return to sustainable levels — whether through conscious choices and planning or through diseases, famine, plague, wars, and conflicts.

In the global ecological crisis of the twenty-first century, it is clear that the modernist vision has been refuted, whereas some basic principles of Malthus have been vindicated. Although Malthus used a static model of calculation and failed to account for factors such as how technological innovation could increase food supplies, the gains artificially obtained through chemicals and agribusiness have peaked, leaving depleted lands and soils. Throughout the world, human populations are facing unprecedented shortages of water, land, food, oil, and other resources. Increasing demand for decreasing resources leads to competition, conflict, and war.[41] From Bush's invasion of Iraq for control of oil, to battles over water in the Nile Basin, and to struggles over timber, gems and minerals in Borneo and Sierra Leone, the same Malthusian pattern is playing out throughout the globe. One key reason for the current genocidal violence in Darfur, for instance, is lack of water and agricultural land. To a significant degree, conflicts throughout the Middle East over the last few decades have been over land and water rights. And of course the Bush administration invaded Iraq in large part to gain access to its oil, and the United States is currently battling China for control of oil and gas flows in Central Asia and compromising national autonomy and security through dependence on oil from the Arab world.

As realized by many politicians, global warming and resource scarcity will emerge as key national security concerns. As sea levels rise, world populations grow, and consumption rates soar, millions of people will become environmental refuges. Water and energy will become increasingly costly and scarce, grasslands will become deserts, and brutal conflicts over increasingly scare resources will flare throughout the globe. Underdeveloped, poor, and unstable nations will be hit the hardest and experience the most social and political chaos, but the wealthier nations will be drawn into the maelstrom with humanitarian and military operations. Hurricane Katrina, which wiped out the U.S. Gulf Coast in 2005, was just a hint of the social and ecological crises to come, such as global climate change portends.

The realization of Malthus' dystopian vision in no way validates his political views and policy suggestions. Malthus was an elitist, capitalist champion, and Social Darwinist who held workers, the poor, and the unfortunate 
in contempt. He argued against policies assisting the disenfranchised on the grounds that aid would only increase their dependence on government and aggravate population problems. In the early twentieth century United States, "neo-Malthusianism" emerged as a racist doctrine used to influence immigration legislation. In the late 1940s, neoMalthusians argued against the use of pesticides and antibiotics to control malaria and infections in third world countries. In the 1960s, neo-Malthusian arguments reached an audience of millions with Paul Erlich's book, The Population Bomb (1968), which made dire and false predictions of immanent catastrophe and tended to scapegoat people of color in underdeveloped nations. In the 1980s and 1990s, Malthusian ideas influenced deep ecology and radical environmental groups such as Earth First!, leading some to argue against famine relief for starving masses in Ethiopia, as others even applauded AIDS as an ideal form of population control.[42]

While positive in their recognition of ecology, the limits of nature, and the dangers of overpopulation, Malthusian approaches suffer from two key problems. First, they present the forced option of either turning our backs on the needy to advance the long-term good, or helping them and thereby exacerbating population growth. Malthusians don't recognize the viability of a third possibility, whereby governments assist those suffering from poverty, famine, and other problems, as they also work to reduce population growth by addressing its root causes in social dynamicssuch as involve imperialism, economic dependency, lack of education, and patriarchal control of women. Thus, a second major problem with Malthusianism is that it reduces population growth to a strictly biological issue, thereby abstracting it from its overall social context.

We must respond to human overpopulation problems with compassion and respect for the rights, dignity, and value of each human life, rather than with ecological reasoning abstracted from a social-political context. It is unthinkable to regard humans as mere problems, abstract masses devoid of individuality, a disturbance in ecosystems, or a drain on public resources to be removed by any means. That was the attitude of Nazi Germany, which saw Jews, workers, homosexuals, socialists, and others as genetic pollutants and social irritants that only a final solution could remove. Typically, Western governments do not show indifference to starving masses in Ethiopia and elsewhere on the assumption that aid would only increase their dependence on aid and boost population growth. There are alternative solutions, such as involve facilitating the economic independence and boosting the agricultural capacities of "undeveloped" nations. Western states send aid to starving people even if it might aggravate the problem because they recognize - to varying degrees_responsibilities to help unfortunate people in undeveloped nations who are suffering in the here and now, without dehumanizing appeals to ecological balances in the future. And we certainly do not talk of culling human populations and making a profitable sport of it - unless, that is, we are Nazis enamored with power and contemptuous of life, administrating violence and death on a mass level, applying bureaucratic, Taylorized logic to dehumanized mass populations with icy cold detachment.

So, when it comes to the overpopulation of elephants in some South African national parks, to a species universally acknowledged to be amazingly intelligent and sophisticated, why do ecologists, government officials, park managers, hunters, and others advocate eco-fascist, final solution policies? Why do they promote the mass murder of beings renown for their intellectual, emotional, and social complexity? If nations mobilize to send food to starving masses (perhaps thereby allowing their populations to increase), why don't they take the same lengths to address problems resulting from “overpopulating” animals? Why is the first and main solution to pick up a gun? Why aren't conservationists and park officials aggressively pursuing alternatives and taking extraordinary lengths to avoid violent responses?

The answers lie in the speciesist devaluation of elephant lives, the elevation of human over nonhuman interests, the pressure from the powerful hunting lobbies and ivory trade, and the value of elephants as food and resources. Eco-fascist, neo-Malthusian attitudes are blatantly evident, for example, in the views of Dr. Hector Magome, Director of South African National Parks. In a recent statement, he explained that he was "strongly leaning toward culling and we want the public to digest this hard fact." Similarly, Dr. Ian Whyte, elephant specialist at Kruger National Park, said, "No one likes killing elephants, but we have a responsibility to maintain biodiversity."[43]

This is quintessential Malthusianism, where killing is dressed up as realism and utility rather than murder and wrong, and where ecology and ecosystems trump individuals and rights. Magome and Whyte posture as if they alone can penetrate through sentiment and illusion, that only they have the courage to advance the realist view that in areas such as Kruger National Park it is necessary to kill six thousand elephants to protect biodiversity and to forestall greater ecological problems in the future.

In fact, this attitude and policy is not only Malthusian, it is Nazism in pursuit of the final solution to the “elephant problem." Consider the language of a 2005 policy report, which states: "It is recommended that application 
of lethal means, specifically culling, be approved as part and parcel of a range of options for the management of elephant populations. The implementation of culling should be informed by the application of adaptive management principles, while also not excluding the application of and learning from other viable management options." With park bureaucrats negligent for not taking action long ago, and with their backs against the wall to take decisive action and to revivify the ivory market, they reject the many nonviolent alternatives to killing elephants as "too costly and would take too much time to deal with an urgent problem.[44]

Exactly how does this outlook differ from the methodical administration of death through the technological systems of Hitler's Germany? This is not "culling," it is a despicable type of genocide; it is an act akin to ethnic cleansing whereby one group systematically wipes out members of another group deemed the inferior, evil, and threatening "Other."

\section{Scapegoating Elephants}

"What gives man the right to kill an animal, often torture it, so that he can fill his belly with its flesh? We know now, as we
have always known instinctively, that animals can suffer as much as human beings. Their emotions and their sensitivity
are often stronger than those of a human being. Various philosophers and religious leaders tried to convince their disciples
and followers that animals are nothing more than machines without a soul, without feelings. However, anyone who has
ever lived with an animal be it a dog, a bird or even a mouse-knows that this theory is a brazen lie, invented to justify
cruelty."
-Isaac Bashevis Singer

While there is much ado in government and conservation reports about elephant overpopulation in areas such as Kruger National Park, let's be clear that African elephants on the whole (like their Asian counterparts) are an endangered species, and that any renewal of culling policies can revitalize the ivory trade and jeopardize their survival. The rate of decimation is stunning. In 1930, Africa was home to 5-10 million elephants. By 1979, serial cullers reduced their numbers to 1.3 million. Between 1970 and 1989, the elephant population was halved when another million elephants were slaughtered for their ivory tusks. According to one report, "The exploitation of elephant herds on a massive scale began in the 1970s. Organized gangs of poachers used automatic weapons, profited from government corruption, and laundered tons of elephant tusks through several African countries to destinations in Eastern and Western countries.'[45] Today, only 600,000 elephants survive in the South African wild.

The elephant-human conflict is a microcosm of global problems and dynamics, and emerges in a critical time of struggle over diminishing resources in a shrinking earth. Unavoidably, the current era of resource wars raises the specter of Thomas Malthus. But while Malthus saw that scarcity would bring humans into conflict with one another, he didn't predict conflicts between humans and animals over scant land and resources, creating situations where animals are under attack and, quite literally, are often fighting back.

Like humans, chimpanzees, and other animals, elephants have complex minds and social structures. In one dramatic instance of how violence to animals rebounds to affect human society, elephants who suffer from posttraumatic stress disorder, brought on by killing of and separation from family members, grow up psychologically damaged and are more likely to attack humans. In such cases of "elephant aggression," one should not blame the victim, but rather examine the causes of the behavior in human predation. It is quite possible animals such as African elephants understand the short and long-term threat humans pose to them, harbor anger towards them, and consciously resist and strike back. Thus, in some ways, chimpanzees, elephants, and other animals are forming their own Animal Liberation Front, quite apart from radical animal rights activists who don masks, operate in underground cells, and clandestinely liberate animals from cages and attack the property (never the person) of animal exploiters such as Huntingdon Life Sciences. One can hardly expect animals to win their freedom, however, without help from animal rights activists and an enlightened public.

Amidst complaints that elephants trample crops, damage ecosystems, and endanger and often take human lives, it is clear that elephants are being scapegoated for problems they did not create and, in the form of habitat destruction, many critics argue does not exist. The Canadian sealing industry blames seals for depleti'ng fish population, thereby providing an eco-fascist justification for the slaughter of over 300,000 baby seals every year. But it is the fishermen, not the seals, who are depleting the fish. Similarly, African elephants are not responsible for ecological degradation and shrinking biodiversity, as the fault lies ultimately with human beings. Elephants are blamed for damage wrought 
by humans in order to justify their slaughter, and thus are scapegoated like seals in Canada. Making elephants liable for alleged ecological problems opens the door to further genocide in Africa's national parks, a pogrom sure to take place out of sight of Western tourists who largely abhor culling.

But elephant predation is the inevitable result of human predation, and people are blaming the victim. In reality, farmers, loggers, ranchers, hunters, and other commercial interests, buoyed by a growing human population and rapacious market demands, have destroyed and diminished natural habitats, such that roaming elephants inevitably come into contact and conflict with swelling human communities. Far before elephant numbers began to climb in certain areas, environments already were degraded by farming, ranching, timber, mining, and other exploitative industries. To keep up with expanding populations, growing markets, and insatiable consumer appetites, industry and development projects have destroyed natural habitats, leaving only fragmented patches of parks and protected areas.

Subsequently, human and elephant interests clash violently. According to one report, "In central Africa, large tracts of elephant habitat are threatened by slash-and-burn agriculture and by large commercial logging operations, while throughout Africa less than 20 per cent of elephant range is protected in parks and reserves. Many herds are now confined to isolated protected areas. As a result, when elephants try to follow traditional migration corridors through what was once forest or savannah, they are confronted with roads, fields, and villages. This inevitably leads to conflict with local people. Further conflict arises in instances when elephant populations grow and can no longer disperse naturally across their former range. This can lead to local overcrowding, as in the case in some parts of southern Africa where increasing elephant populations cause damage to their habitat. Elephants have found farmers' crops attractive as an alternative food source. The cost for a farmer in this instance is high: as elephants can eat up to $300 \mathrm{~kg}$ of food every day, even a small herd can devastate a farm during one night's foraging. Human-elephant conflicts can be fatal to for both humans and elephants. Many wildlife authorities shoot animals that are harming humans and their property; local people also sometimes kill elephants in retaliation for attacks. In turn, elephants can also sometimes attack people when their paths cross." [46]

Ecological destabilization has direct human causes. At Wangi National Park, for instance, park officials created waterholes for tourists flocking to the area, but they also became a year round habitat for elephants and other animals, leading to major changes in vegetation and the balance of species.[47] At Kruger National Park, flawed policies such as water point provision as well as culling have upset natural mechanisms of population regulation, artificially inflating elephant numbers out of balance with the environment.[48] Rather than a solution to elephant overpopulation, culling and slaughter have helped to cause it: "Removing elephants has an ecological impact too: Decimation of elephant populations by the ivory trade, especially the huge volumes trafficked in the 1800s, removed elephants over wide areas and had cascading impacts on vegetation and other species allowing tree species, such as marula and various acacias, to colonize and become established in a way that may have been unusual in ecological time."'[49] Thus, further culling will only worsen the ecological problems such senseless slaughter tries to avoid.

Many critics, moreover, question the root assumption and justification for culling, by emphasizing a lack of evidence for the claim that elephants are damaging environments and biodiversity. As one critic writes, "Despite decades of draconian population management, there is little reliable evidence of the outcomes of elephant-habitat interactions, with respect to other species and to elephants themselves. However, amidst this uncertainty, there is no evidence to support a reasonable expectation of imminent, irreversible damage to biodiversity, despite SANParks' claims to the contrary. Examples often given within South Africa of elephants' catastrophic damage to ecosystems are, in fact, myths. Tsavo National Park in Kenya was not destroyed (despite misleading reports to the contrary) and remains dynamic, with diverse and productive plant and wildlife communities."[50] In comparison to some other conservation areas, the report states, "Kruger Park is densely covered in bush ...none of the 1,922 plant species in the Kruger Park are endangered, nor are any of the plant communities under threat." The report claims that "there is little reason to fear that biodiversity is under imminent risk in Kruger ... and every reason to believe that imaginative elephant management approaches can result in population mechanisms that will promote heterogeneity within the Park and actually increase biodiversity in the longer term.”

In searching for root causes of environmental destruction, human-animal conflicts, and possible elephant overpopulation in some areas, we must also point a critical figure at the destructive effects of thousands of unregulated game farming and ranching industries operating in South Africa. Universally, whether speaking of elephants or deer, a core justification hunters offer for their bloodsport is that shooting animals dead promotes ecological balance by reducing excess population numbers. The evidence suggests, however, that hunting has the opposite effect. As Pickover explains, hunters in South Africa disrupt ecological balance and cause natural selection in reverse, as "they 
produce favoured species at the expense of the less favoured, overstock to keep up with demand, exterminate large predators and severely cull small ones ... feed artificially, manipulate habitat as ordinary farmers do, introduce nonindigenous species and strains, and genetically manipulate wild animals."[51] By taking animals with the biggest manes and horns and targeting the strong and healthy instead of the weak and sick, hunting interferes with animal social structures, natural ecologies, and the balance of nature. Game farming disrupts natural selection and genetics as it destroys habitat; the land possessed by private individuals is "alternated and manipulated intensively, and this in turn has detrimental effects on the diversity and abundance of many bird species, small mammals and reptiles that depend on bush and forest habitats. The biological and conservation value of privately owned commercial ranches are therefore very limited.”[52]

Thus, if governmental agencies and conservation organizations are truly interested in protecting habits and species, it would seem more logical to target agriculture, commercial logging, game farming, park mismanagement, and hunting organizations rather than elephants. Culling elephants is a hideous case of blaming the victim. But logic matters little where politics prevails over "science" and special interest groups overwhelm the larger good of humans, animals, and the environment. Let's be clear that the blame game runs both ways: we can justly claim that people steal from elephants and other species; that people are immense lethal threats to elephant lives, families, and communities. Perhaps it is humans who should retreat and make room for elephants, and other species as well.[53]

\section{| The Dialectic of Ecotourism}

"For every thousand people hacking at the branches of the tree of evil, only one is hacking at the root." - Henry David Thoreau

Many South African communities and animal advocates worldwide have proposed that the best solution to the human-elephant conflict is through building networks of "eco-tourism" that market elephants to tourists who would visit South Africa principally to view elephants in the "wild" and whose dollars, euros, and yen would rebuild the economic infrastructure of states and communities. Ecotourism is a significant leap forward beyond culling and primitive exploitation of elephants in the hunting and trade industries, for it reverses priorities - by endowing elephants with more value alive than dead —as it potentially undoes and resolves the opposition between human and animal interests, such that what benefits elephants benefits humans as well, and vice versa.[54] Eco-tourism can help mitigate or dissolve the conflict between people and elephants, and enable people to see them in more positive terms. To underscore this point, a hopeful sign of change is evident in the outlook of Muzarabani district chief executive, Luckson Chisanduro, who stated that, "People are beginning to understand that there is a need to preserve the elephant, not just for the income but because it is our inheritance." [55]

Such insights lead not to actions that exclude elephants from communities with wire fences, but rather include them as a crucial part of their history and identity. One way of mediating the human-elephant "conflict" is through ecotourism whereby communities benefit. Ecotourism is based on the recognition that elephants have more value for communities when alive rather than dead, and that the economic benefits are greater than poaching and hunting, more sustainable, and, in principle, more equally distributed among community members,

If the sole focus of African orientation to elephants is on economics rather than ethics, on what benefits humans not animals, it is crucial to emphasize that there is far more economic value and gain in ecotourism than in animal farming and hunting. As one report explains, "Value can be added more effectively to wildlife existence values through tourism, and related employment and service industries supporting ... wildlife conservation, rather than treating the protected area as a farm for delivering animal products ... revenue generation from tourism is significantly greater than from 'cropping' of wildlife, and photo-tourism offers greater opportunities for investment and added value than consumptive utilization, which is limited by the "offtake-determined threshold of revenues." [56]

In other words, African nations and communities will benefit in the long-term far more when Westerns come to shoot elephants with a camera rather than a gun and the elephant is treated as a vital part of the community rather than as an enemy or pest. A complimentary tactic to ecotourism is organizing a massive boycott against traveling to South Africa should the government and park system resume, or threaten to resume, culling. In the schizophrenic Western mindset that promotes kindness to some animals (cats, dogs, horses, dolphins, and elephants) and killing of other animals (e.g., rats and mice in laboratories and cows, pigs, chickens, and turkeys in factory farms 
and slaughterhouses), significant numbers of Americans and Europeans hold affection for elephants, condemn their killing, and could be mobilized for an economic boycott that might have a significant detrimental impact on the South African economy. Given Western sentiments and spending power, "the potential risks to South Africa's tourism industry if elephant culling is resumed are enormous; in 2002 tourism earned South Africa R72 .5 billion (U.S.\$7.2 billion) in revenue (7.1\% of GDP) and generated 1.15 million jobs.’"[57]

Despite its immense advantages, ecotourism is problematic on moral and political levels because it does not break with commodification logic and the instrumentalist mindset that sees elephants in terms of extrinsic rather than intrinsic value, and alone it is an inadequate reform measure that fails to engage the root causes of interlocking systems of domination, exploitation, and oppression. Individuals, organizations, and communities promoting ecotourism want to stop poaching, protect elephants, and guarantee a space for their existence, but for pragmatic not moral reasons, because elephants bring them economic benefits, not because they are subjects of a life with intrinsic value. Some champions of ecotourism also sanction the "sustainable" killing of elephants.

In direct opposition to the utilitarian and instrumentalist mentality of conservationist and welfare groups, animal rights advocates insist that animals have intrinsic value, whereby their lives are purposeful and meaningful entirely apart from their utility to humans; they thereby reject the instrumentalist framework that reduces subjects to objects and views animals as resources, commodities, property, and mere means to human ends. The animal rights perspective renounces the oxymoronic "sustainable use" and "responsible hunting" policies promoted by speciesist conservationists and animal welfare groups such as the World Wildlife Fund.[58] The moral repugnance of ecotourism can be better recognized by comparing the utilitarian treatment of elephants with the exploitation of "primitive cultures" in human zoos or "tourist performances." Neither people nor animals are harmed, and they benefit from their commodification and objectification (whether by living rather than dying at the hands of poachers, in the case of elephants, or deriving money from their display, as might occur with indigenous cultures), but they are nonetheless viewed as means for the ends of another rather than ends-in-themselves, and thereby denigrated and demeaned in significant ways.

A popular philosophy that flaunts human arrogance is the idea that "elephants can stay if they pay their own way." This suggests, first, that elephants have no right to exist in their homeland which they have been occupying for sixty million years before humans evolved and claimed eminent domain over the entire planet. From this utilitarian and capitalist standpoint, the value of elephant life is entirely contingent on their ability to perform as laborers in a global commodity market at levels high enough to cover the costs of park maintenance. Otherwise, their lives are not worth the time and money necessary to "preserve" or "manage" them, and what value they have in their tusks and flesh will be taken in a hail of bullets. This ingrate mentality ignores the fact that in their exotic allure, fascinating nature, identification with the mystique and beauty of Africa, and stimulants of the ecotourist industry, elephants have already paid their way, time and time again, and they can continue to many times over if South Africa awakens to the fact-if only from within the entrenched market and instrumentalist mentality — that elephants are worth much more alive than dead.

While boycotts and ecotourism can be effective tactics, they are hardly the only weapons needed in the war against animal slavery and domination in all forms. Travel and economic boycotts of South Africa by corporations, banks, and individuals were important contributors to ending the apartheid system, but hardly altered the basic structures of poverty, inequality, and exploitation. Under the crushing weight of Western market imperialism, the continent's social structures and ecological systems continue to deteriorate as African elites and politicians-including Nelson Mandela-embrace neoliberalism and hand Africa over to the hands of global capitalism and world banks. Similarly, should South Africa resume elephant culling, a major tourist boycott could have a significant economic impact and thereby exert political pressure to stop further slaughter, but it would hardly suffice to change the dynamics driving animal exploitation. Touted as the panacea to problems and conflicts and as a model of sustainability, ecotourism itself is potentially unsustainable and ecologically destructive. Its success is a recipe for its failure to the degree that it achieves the goal of attracting hordes of tourists to national parks, yielding the unintended consequence-like the plan to attract tourists to Yellowstone National Park in the United States_of burdening the environment, disrupting wildlife, and bringing about a need for roads and hotels in undeveloped areas.

The struggle for animal rights and liberation is a moral ideal and long-term goal, such that its moral purity and ultimate objectives exist in tension with pressing practical considerations and the urgent needs of the present, such as are defined by the rapid destruction of habitat, species extinction, and the major push of the South African government and park system to resume culling. With this tension in mind-between immediate exigencies and long- 
range goals, between abstract ideals and concrete political complexities — we must admit that it is far better that South Africans instrumentalize elephants for their worth as living beings rather than as corpses and dismembered body parts for consumption and market trade. Undoubtedly, the objectification of elephants in the ecotourism industry is infinitely better than their reification in the ivory, meat, and skin trade.

While still a utilitarian and exploitative outlook-one need think only of the moral problems in a parallel form of exploitation of "primitive cultures" as tourist spectacles and mere means for the end of profit-ecotourism may be the most realistic approach in the current context where global capitalism squeezes Africa from one side and, as a direct result, poverty exerts its crippling pressures from another side. While ecotourism depends on democratization, it also can help foster the process since a key objective of ecotourism (economic benefit for the whole community) can only be realized within a society that overthrows corrupt elites, places power directly in the hands of community members themselves, and thereby ensures a relatively equal distribution of money.

Within the constraints of this utilitarian, market-oriented, and humanist context, animal liberationists can work to further mitigate the "conflict" between people and elephants, and encourage African people to see elephants as allies rather than enemies, as fellow beings rather than pests. They can promulgate their moral message that animals have the same basic rights as humans; that they are subjects of a life, not objects, resources, commodities, and human property; and that they should be treated with respect and as ends-in-themselves not mere means to human interests.

\section{| Contextualizing Social and Ecological Crises}

"For to be free is not merely to cast off one's chains, but to live in a way that respects and enhances the freedom of others."

-Nelson Mandela

Afflicted by violence, overpopulation, hunger, disease, poverty, inequality, and shortages of water, food, and land, South Africa mirrors the crises plaguing much of the world which has been ravaged, plundered, and impoverished by global capitalism and its market and growth imperatives. We are at war with one another in large part because we have long ago waged war against other species and the earth as a whole. The devastation societies inflict upon other species and nature ricochets with equally devastating effects on human societies. The human-elephant conflict is just one of many indicators of a world out of joint, of an stressed and imbalanced planet plagued by problems that are so deep, systemic, and interconnected that they can only be solved by critical holistic thinking; new psychologies, ethics, and identities; and revolutionary change on all levels including energy and transportation technologies, agriculture, politics, and economics.

In South Africa and elsewhere, the social-ecological crisis human beings face must be examined in a searching way-through an approach that identifies root causes not superficial effects; that searches for long-term solutions not quick, pseudo-fixes; and that promotes paradigm shifts in thinking rather than repacking the erroneous concepts and worldviews that have spawned and perpetuated the crises and catastrophes that jeopardize the future of human existence and biodiversity.

Trying to solve the "elephant overpopulation problem" with guns, violence, and terrorism exemplifies the alienated and destructive consciousness humankind so desperately needs to supersede if future generations will have a life that is not, in Hobbes' famous words, "short, brutish, and nasty." Michele Pickover cogently reminds us that "South Africa has a history of resorting to violence as a means of solving problems. So when it comes to the issue of elephant management in national parks there is a lot of pressure on authorities by vested interest groups who want to see elephants killed for selfish purposes. We should resist this pressure and, in our treatment of wildlife, we should strive to embody the more humane values that underpin the new ["open" and "democratic"] South Africa."[59]

No attempt to understand and resolve the complex problems confronting besieged nations such as South Africa will be adequate if detached from a systemic critique of capitalism and imperialism, one that reveals the inherent logic of capitalism that leads to imperialism.[60] Analysis of the myriad of problems plaguing Africaits people, animals, and environment-must begin with the destructive legacies of capitalism, colonialism, neocolonialism, corporate globalization, and predatory banking schemes. The devastation of the natural environment, the colonization of wild spaces, the forces driving people to chop down trees and shoot down elephants-such dynamics are incomprehensible apart from the history of imperialism. The unbroken legacy of Western exploitation, from the fifteenth century to the present, has had devastating consequences throughout Africa in forms such as 
ecological devastation, resource depletion, poverty, famine, disease, political corruption, authoritarian governments, violence, and genocide.

Like Brazil and Latin American nations, Africa is a classic case of underdevelopment — whereby an imperialist power willfully impoverishes southern nations, stealing their natural resources, exploiting their labor power, and appropriating their land to grow food and cash crops for export rather than domestic consumption, as they dump surplus wheat and other commodities in poor countries to further undermine their economies.[61] Like a giant siphon or vacuum, corporations, imperialist nation states, and global financial and legal institutions have drained the resources, wealth, and health of southern nations such as Africa. Forces of underdevelopment have transformed independent and often prosperous nations into hellish lands afflicted with poverty, starvation, disease, gross inequality, violence, and a vastly diminished life span.

Despite the decolonialization process that began in the $1960 \mathrm{~s}$, Western transnational corporations such as Shell Oil, legal structures such as the World Trade Organization, and financial institutions such as the International Monetary Fund and the World Bank have strengthened the Western stranglehold on Africa by providing loans attached with the political strings of "structural adjustment" (which aim to lower wages and XX) and onerous debt obligations. In addition, corrupt dictators serving Western interests have ruled African countries with an iron fist as they stuffed their own pockets with millions of dollars in loans and aid meant to alleviate the suffering of their people.

Over the span of five centuries, the exploitation of Africa by Western states and corporate powers has had a catastrophic impact on society and nature, proliferating suffering and spawning endless crises. Despite national liberation movements that emerged after World War II, Western domination is today more powerful than ever, poverty rates continue to rise, the specter of AIDS has brought unparalleled suffering and death, and genocide erupts among clans and tribes. No matter what group governs, whether left or right, black or white, South Africa and the continent as a whole is subservient to foreign capital. As Leo Zeilig writes, "The ANC government ministers denounce the protesters as an 'enemy within,' but the real root of the discontent is neo-liberalism. No other country in Africa has embraced with such craven enthusiasm the agenda of privatisation and the free market. The resulting economic growth has meant considerable dividends for the rich and the middle class. The wealthy live behind their security gates — shuttling between house and shopping malls. Nowadays, everything is done in the malls-all social and consumer activity, including trips to the cinemas, restaurants and bars. This group, though predominately white, has been expanded by a new layer of black professionals ... The largely unchanging poverty of the poor and the working class is almost invisible in apartheid townships, and almost everywhere the interests of private business dominate government policy.”[62]

A radical liberation politics, moreover, seeks to illuminate the intricate connections between social and environmental problems. As demonstrated by theorists such as Murray Bookchin, ecological problems stem from social problems, and thereby require social solutions. [63] One cannot change the destructive environmental dynamics of societies without changing the institutions, power systems, and hierarchical forms of domination that cause, benefit from, and sustain biological meltdown. Corporate destruction of nature on a global scale is enabled by asymmetrical and hierarchical social relations, whereby capitalist powers appropriate the political, legal, economic, and military systems of states in order to bolster and defend their exploitation of labor, animals, resources, and nature.

\section{| Commonalities of Oppression}

"As long as human beings will go on shedding the blood of animals, there will never be any peace. It is one little step from killing animals to creating gas chambers a la Hitler and concentration camps a la Stalin ... all such deeds are done in the name of 'social justice.' There will be no justice as long as man will stand with a knife or with a gun and destroy those who are weaker than he is." - Isaac Bashevis Singer

Human, animal, and earth exploitation are tightly interconnected, such that no one form of exploitation can be abolished without uprooting the others. It is well understood, for instance, that human population rates drop in societies in women are educated and have basic rights. A possible global pandemic of Asian Bird Flu, the result of 
intensive exploitation of birds in factory-farm conditions, could have a devastatingly lethal impact on millions of people. Also, in conditions where people are desperately poor they are more likely to adopt instrumental views of nature, poach animals, and chop down trees in order to survive. Thus, if killing elephants is profitable and beneficial to individuals and communities, we need to eliminate the economic incentive to kill by addressing the root causes of poverty in social relations.

An effective struggle for animal rights and liberation demands tackling issues such as poverty, class domination, economic inequality, political corruption, and the hierarchical organization of society at all levels-from local and national to global relations_ _ such as produced and reproduced throughout human history by racism, sexism, speciesism, and classism (today constructed more deeply than ever on a worldwide scale by transnational/global capitalism). Any viable approach to save animals must also promote the democratization of society, such that crucial decisions and allocations of power and resources are not monopolized by an elite minority to advance their privileges and interests, but rather by communities using democratic decision making procedures to promote autonomy and equality.

The most determinant hierarchy in the current world is class domination, whereby the monopolization of capital, property, and resources goes hand-in-hand with the control of political authority, the legal system, cultural institutions such as education and mass media, and the awesome powers of science and technology. Transnational corporations have hijacked the entire planet to advance their economic interests and political ambitions. Accountable virtually to no one including the governments they bought and control, driven by short-sighted economic motives and power ambitions, corporations thrive by spawning new markets, driving product demand and boundless consumption, devouring all the earth's resources, sending species after species into oblivion, and spewing toxic poisons and pollution to levels great enough to bring about global climate shifts. The grow-or-die system of global capitalism is a runaway train speeding toward oblivion. It cannot ultimately be stopped until market society is replaced with an ecological society, and all hierarchies including the domination of human over nature are abolished in favor of decentralized democracies.

Animal rights and environmental advocates who are misanthropic, single-issue oriented, resistant to work in alliances with other social movements, and pro-capitalist in their political views undercut and can never achieve their goals and objectives. So long as corporations, banks, and dictators control the social, political, and economic structures of societies, animals and the environment will suffer too as elite social interests exercise their power and mightbacked by states, armies, death squads, and assassins — to commander humans, animals, and the earth to further their own interests, whatever the consequences to individuals, families, communities, nations, animals, future generations, and the environment as a whole. The protracted dictatorship of Mobutu Sese-Soko, for instance, provoked civil wars that since 1968 cost the lives of 3.9 million people, as he pillaged the nation's natural resources for profit and funding his armies. These kinds of inseparable social/ecological problems are endemic to social hierarchies, and they cannot be eliminated except through a radical process that dismantles power systems (such as rooted in states and corporations) in order to advance democratization, decentralization, autonomy, and egalitarianism.

Conversely, whereas animal rights advocates need to engage other forms of oppression, form broader political alliances, and evolve in their political vision, human rights advocates need to comprehend the myriad of social and ecological problems that stem from animal exploitation. These problems include well-documented relations between violence toward animals and violence toward humans in families scarred by domestic abuse and throughout society as a whole, erupting in fierce forms such as serial killing. [64] In their quest to develop biological and chemical agents to assassinate their enemies, mad scientists in the service of the former apartheid state tested their prototypes on animals. Human beings would never had been put in such grave danger were animals not held in even more contempt and a strong anti-vivisection movement existed.[65]

There are crucial continuities and similarities among various forms of oppression that often are ignored (e.g., by socialist and Marxist theorists who analyze classism apart from racism, sexism, and, most certainly, speciesism). This is a colossal collapse of critical vision that leads to reductionism in theory and anti-alliance politics in practice. Racism, sexism, and speciesism share a fundamental logic of oppression and are constituted out of similar and overlapping social, institutional, and technological modes of control. Racism, sexism, and speciesism are ideologies of objectification, devaluation, and exclusion. Each belief system is grounded in the conceptual structure of a dualist logic, an institutional structure that mobilizes laws and social relations for domination, and a technological structure that mobilizes a battery of things (such as chains and cages) to advance exploitative goals.

In each case, the conceptual structure underlying the machinery of exploitation is rooted in a binary logic. A 
rigid dichotomy is established between different groups—whites/blacks, men/women, and humans/nonhumansthat denies their commonality and shared interests. But these oppositions are not innocent or unmotivated; they are arranged in a hierarchy that privileges one group as superior and denigrates the other as inferior. As every power system has a justification, conceptual hierarchies are the theory for the practice of dominating marginalized groups through institutional and technological means. But, in every instance of oppression, the alibi of power is arbitraryrooted in fallacies, biases, prejudice, and hostility rather than logic, reason, and a defensible argument.

Throughout the development of Western culture, the rationales for domination have failed to withstand critical scrutiny; increasingly — whether training birds to fight, under paying women in the workplace, or using homophobic or racist slurs - exploitative and discriminatory practices are becoming socially unacceptable and subject to penalty (certainly more for racism and sexism than speciesism now). There is no justification for one being to claim moral superiority over another, simply on the basis of differences relating to race, gender, ethnicity, religion, nationality, sexual preference, and species. The inferior types of being and existence racists, sexists, and speciesists claim that people of color, women, and animals have in fact do not represent an essential nature, but rather are social constructions. As such, these ideologies stem from wholly fallacious interpretations of different types of race, gender, and species.

The essentialism and binary oppositions fundamental to systems of power, hierarchy, and domination have to be challenged in all cases and places. The oppressive regimes of speciesism, racism, and sexism are mutually supporting and reinforcing. In numerous ways, there are deep connections between animal oppression and human oppression, such that attempts to illuminate or eliminate any one form of domination are strongest when related in theory and practice to other forms of domination.

To give some indication of these complex relations by way of concrete examples, we can first examine the connections between speciesism and racism, between animal and human slavery. Beginning in the 1870s, numerous cities including Paris, London, Hamburg, Barcelona, and New York opened new exhibits, called "human zoos.”[66] These pathetic spectacles displayed indigenous peoples (Africans, Samoans, and others) in cages, often semi-nude or nude, as living trophies demonstrating white European superiority over "primitive" dark cultures. Tens of millions of people gawked "savage" and "exotic" peoples, their first and lasting impression of the colonial Other. In 1906, Madison Grant, the head of the New York Zoological Society and a prominent eugenicist, exhibited pigmy Ota Benga at the Bronx Zoo. Grant placed him in a cage with an orangutan, and labeled the exhibit "The Missing Link," thus suggesting that Africans such as Benga were closer to apes than to human beings. Human zoos, of course, would not have been possible without the prior existence of animal zoos, which were created in the nineteenth century when colonialists captured and displayed wild animals in a similar display of human supremacy and power over nature.

Thus, institutions first used to exploit animals were adapted to exploit human beings, framing indigenous peoples as sub-human animals. With their large worldwide audience, zoos, in fact, were important institutions for the construction and dissemination of racist ideologies, eugenics, and Social Darwininism, thereby legitimating colonialism as just and right, as the path to Progress. Anthropology and the social sciences were accomplices to this enterprise, as racist theories became increasingly influential in society. The systematic extermination of millions of Jews and others by the Nazis was inspired, informed, and justified by racist theories and "might is right" worldviews, such as zoos helped to construct and bring to a mass audience.

Indeed, there are profound relationships between speciesism and racism, animal and human exploitation, and mass animal slaughter and human genocide. As Charles Patterson demonstrates in The Eternal Treblinka: Our Treatment of Animals and the Holocaust, there are deep and disturbing connections between the enslavement of animals and human slavery; between the breeding of domesticated animals and compulsory sterilization, euthanasia, and genocide; and between the assembly-line killing of animals in slaughterhouses and the mass killing techniques employed in Nazi concentration camps. [67] "A better understanding of these connections," Patterson states, "should help make our planet a more humane and livable place for all of us-people and animals alike, A new awareness is essential for the survival of our endangered planet."[68] The construction of industrial stockyards, the total objectification of other species, and the mass mechanized killing of animals should have come as a warning to humanity that such a process might one day be applied to humans, as it was in Nazi Germany. Thus, the poignant relevance of a quote attributed to Theodor Adorno, to the effect that, "Auschwitz begins wherever someone looks at a slaughterhouse and thinks: they're only animals."

Similarly, in The Dreaded Comparison: Human and Animal Slavery, Marjorie Spiegel shows that the exploitation of animals provided the models, metaphors, technologies, and practices for the dehumanization and enslavement 
of blacks.[69] From castration and chaining to branding and ear cropping and breeding slaves like horses and mules, white Europeans drew on a long history of subjugating animals to oppress blacks. In the nineteenth century a popular sentiment was that blacks were a "sub-species," more like gorillas than full-fledged humans. Once perceived as beasts, blacks were treated accordingly; pariahs from the moral community, animals provided a convenient discard bin in which to throw blacks. By demeaning people of color as "monkeys," "beasts of burden," and "filthy animals," animal metaphors-derived from systems of speciesist exploitation-facilitated and legitimated the institution of slavery. The denigration of any people as a type of animal is a potential prelude to violence and genocide.

Once Europeans began the colonization of Africa in the fifteenth century, the metaphors, models, and technologies used to exploit animals were applied to human slaves. Stealing Africans from their native environment and homeland, breaking up families, wrapping chains around their bodies, shipping them in cramped quarters across continents for weeks or months with no regard for their suffering, branding their skin with a hot iron to mark them as property, auctioning them as servants, separating family members who scream in anguish, breeding them for service and labor, exploiting them for profit, beating them in rages of hatred and anger, and killing them in vast numbersall these horrors and countless others inflicted on black slaves began with the exploitation of animal slaves.

Popular anthropological schemes of the nineteenth century placed "Aryans" on the top and blacks at the bottom; previously referred to with terms such as "lineage," nineteenth-century concepts of race were clear examples of scientific racism. As Felipe Fernandez Armesto observes: "Racism provided ample justification for the victimization, persecution, oppression, and extermination of some groups by others. Working off the initial hierarchy forced in relation to animals, it became necessary—even for advocates of Nazism or apartheid—to insist that different human groups constituted different species, sub-species, or potential species." [70] By the late-twentieth century, however, science had discredited scientific races, for "Not only were there no inferior races: there are no races; there is practically no racial differentiation among humans. Although we may look different from one another, the genetic space between the most widely separated humans is tiny, by comparison with other species. The same science has exploded the notion of human 'subspecies'.' [71]

There are important parallels of speciesism to racism and sexism in the elevation of male rationality to the touchstone for judging moral worth. The same arguments European colonialists used to justify exploiting Africansthat they were less than human and inferior to white Europeans in rational capacities—are the very same justifications humans use to exploit, consume, and kill animals. There is undoubtedly a significant link between animal exploitation and human exploitation as ancient speciesist arguments were adapted to underpin modern racist outlooks and are parallel as well to patriarchal ideology that women are emotional creatures incapable of advanced reasoning.

Moreover, the confinement and killing of billions of animals in factory farm and slaughterhouse systems has a profound negative impact on the environment and thus on human life. To provide grazing land for cattle, animal agriculture industries destroy habitats and rainforests and habitats, and spread desertification. The release of carbon dioxide from cut forests, use of fertilizers, and release of methane gas from billions of cattle are major causes of ozone deterioration and global warming. In a world where energy, land, and water are scarce, the global meat production/consumption system is fueled by enormous quantities of resources. Moreover, in the shift from food to feed production, most crops are grown for animal feed rather than human food, wasting precious crops.

The relation between agribusiness and resource depletion is particularly poignant in the context of Africa as a whole, for it raises the specter of famine. One of the leading causes of world hunger, in fact, is animal agriculture and meat consumption, whereby most of the world's land, water, and crops are fed to animals fattened and slaughtered for human consumption. Besides the toll this system takes on animals and the environment, and its impact on human health, it is an incredibly inefficient use of scare land and water resources. As Jeremy Rifkin explains,

People go hungry because much of arable land is used to grow feed grain for animals rather than people. In the United States, 157 million tons of cereals, legumes and vegetable protein-all suitable for human consumption-is fed to livestock to produce just 28 million tons of animal protein in the form of meat.

In developing countries, using land to create an artificial food chain has resulted in misery for hundreds of millions of people. An acre of cereal produces five times more protein than an acre used for meat production; legumes such as beans, peas and lentils can produce 10 times more protein and, in the case of soya, 30 times more ....

Despite the rich diversity of foods found all over the world, one third of its population does not have enough to eat. Today, hunger is a massive problem in many parts of Africa, Asia and South America and the future is not looking good. The global population is set to rise from 6.1 billion ... to 9.3 billion by 2050 and Worldwatch reports forecast severe global food shortages leading to famine on an unprecedented scale. 
This misery is partly a direct result of our desire to eat meat. Children in the developing world starve next to fields of food destined for export as animal feed, to support the meat-hungry cultures of the rich world. While millions die, one third of the world's grain production is fed to farmed animals in rich countries....

If animal farming were to stop and we were to use the land to grow grain to feed ourselves, we could feed every single person on this planet. Consuming crops directly-rather than feeding them to animals and then eating animals-is a far more efficient way to feed the world ...

By squandering the vast bulk of land and water resources, resources that could produce far greater quantities of nutrient rich food in a plant-based agriculture, the global meat culture directly contributes to world hunger. Moreover, the global meat exacerbates inequality and poverty among the world's peoples, as resources from impoverished Southern nations flow to wealthy Northern nations.

The human consequences of the global shift from food to feed production were dramatically evident in 1984, when thousands of Ethiopians were dying of famine each day. The problem was not that Ethiopia had no viable land on which to grow crops and feed its people, but that it was using millions of acres of land to produce linseed cake, cottonseed cake, and rapeseed meal for livestock feed to export to Europe. Rifkin notes the perverse irony of such an irrational and unsustainable system of food production: "Around six billion people share the planet, one quarter in the rich north and three quarters in the poor south. While people in rich countries diet because they eat too much, many in the developing world do not have enough food simply to ensure their bodies work properly and stay alive.[72]

And yet, despite the overwhelming, irrefutable fact of the immense destructive power (to humans, animals, and the earth alike) of the global meat and dairy industries, institutions such as the World Hunger Organization, the IMF, and the World Bank promote the destructive myth that factory farming is the best way to feed a hungry world, as advertisements promoting meat and diary consumption and fast food chains such as McDonalds and KFC proliferate throughout the world. In contexts such as this, people must recognize the larger significance of vegetarianism and veganism—not only as a health and personal growth movement, but also as a social justice and environmental movement.

The tragedy of famine clearly does not stem from "natural" causes such as scarcity and the "stinginess" of nature, but rather from the socio-economic dynamics of meat-based agriculture, the appropriate of land to export cash crops to the Western world rather than to feed domestic populations, the domination of transnational corporations and global banking institutions, and the corruption of national rulers.

Given just a few examples of the devastating effect of animal exploitation on the social and natural worlds, the oft-heard diatribes that animal rights activists care more about animals than humans, are elitists, or have misplaced priorities misses the point entirely. Such a dismissive reaction represents a moral failure to respond to the enormity of animal suffering and an intellectual failure to understand the enormous social and environmental implications of the human attempt to subjugate, colonize, and plunder the earth and its sundry species. Besides the speciesist assumption that animal suffering does not warrant a serious moral or political response, this objection proceeds from an atomistic outlook unable to see the connections between animal exploitation, environmental destruction, patriarchy, racism, violence, and world hunger. The exploitation of animals causes profound social and environmental problems for the human world itself, such that we should stop treating animal rights as trivial to human and environmental problems, and rather see it as fundamental to resolving crises in both realms.

\title{
Multiperspectivalism, Alliance Politics, and Total Liberation: Renewing Systemic Analysis and Politics
}

\author{
"Let there be justice for all. Let there be peace for all."
}

-Nelson Mandela

Truly, Africa is a continent overwhelmed with human suffering that has deep causal roots in European imperialism, American neo-imperialism, and the predatory nature of contemporary transnational corporations and banking structures. The wails and cries of babies dying from hunger and people attacked by machetes pierce the air. But the answer to human victimization does not lie in victimizing animals and using a reckless short-term mentality of exploitation of elephants and wildlife as a whole in a way that corrupts and perverts the core meaning 
of sustainability. It is crucial to grasp the economic and political roots of the problems afflicting Africa from within a global context, while also understanding how different forms of oppression—such as racism, sexism, speciesism, and classism-overlap, interrelate, and reinforce one another.

Human and animal liberation movements are inseparable, such that none can be free until all are free. Whereas people in South Africa and around the globe cannot develop peaceful, humane, and sustainable societies so long as they exploit animals (and thereby disrupt the environment in profound ways), so animals cannot be freed from slavery without deep social and psychological changes in human societies and psychologies. The social changes entail not mere reforms such as "government accountability," but rather dismantling the entire system of transnational capitalism rooted in unsustainable and omnicidal imperatives for the endless pursuit of profit, accumulation, resource extraction, labor exploitation, and growth.

If conducted intelligently, democratization can destroy the power of the hunting and ivory trade lobbies, as it redistributes monetary resources, eradicates poverty, and nullifies the motivation of poor people who kill animals not out of malice, a profit motive, or revenge (for eating or trampling one's crops, for instance), but rather economic survival. But it is not enough to democratize power if political change does not also eradicate the pathologies of speciesism and domineering humanism, for this only redistributes the authority and capacities to exploit and kill. There is no guarantee that villagers - as cruel and speciesist as anyone else-would treat animals more respectfully than corporations, states, and "conservation" organizations. However progressive the changing political climate may be, benighted mindsets will prevail, such that the land is objectified as a "farm" for delivering animal products, and animals themselves are reified as "harvestable resources." This is the prevailing model among African communities today that experiment with ecotourism and democracy within the utilitarian and speciesist limitations of sustainable use models.

Since decentralization and democratization processes may mean nothing more for animals than broadening human supremacism and collectivized policy of killing, then the process of revolutionary change must also promote profound transformations in human identity, such that people renounce dominator mentalities at all levels-not only in relation to other humans but also to other species and the earth as a whole_-and adopt an ethics of respect for life that over time replaces the experience of alienation from nature with a sense of connectedness rooted in ecological knowledge and emotional connectedness.

Vast social, political, and economic changes by themselves are inadequate to construct an egalitarian, ecological, and viable world unless accompanied by equally profound psychological changes. We need a Copernican revolution whereby people abandon humanist arrogance and predatory practices and realize that they belong to the earth and the earth does not belong to them. Unless developed along with moral education, democratization can be nothing but the broadening of species apartheid and the power to kill. Consequently, people can learn to respect the earth and other species for their intrinsic value, not as a resource for their use and benefit, and take their rightful place as citizens within a vast biocommunity where as citizens of the earth their universal rights come with profound responsibilities toward all nature and life.

The purging of violence needed in South Africa and elsewhere cannot transpire so long as animals are hunted and exploited. Still today, the "new" South Africa is struggling against hate, ignorance, prejudice, and violence in order to form a more enlightened and perfect union, and people will truly grow and prosper once they extend rights, protections, and respect to other species who are part of the evolutionary adventure of life and essential to ecological balance.

To spin the dialectical wheel once more, such that we avoid the trap of naive, apolitical, new-age thinking (rife in the Western animal advocacy movement), we must emphasize that deep psychological change is not enough to resolve the global crisis if not coupled with radical social transformation that unfolds through decentralization and democratization processes at all levels of society on a global basis. South Africa needs democracy as much as it needs moral renewal, a purging of violence that cannot transpire so long as animals are hunted and exploited.

The next logical and necessary step in social and moral evolution is yet to be taken, although there are encouraging signs that societies_ — on an ever-broadening global scale_-are beginning to transform their outlooks and relations with animals by taking stands against their exploitation, recognizing their cognitive and social complexity, and acknowledging that as sentient beings they have basic rights—such as to bodily integrity, freedom of choice and movement, autonomy, and a viable natural environment.

The animal liberation struggle is one of the most progressive and important social movements on the planet today because it is addressing root causes of the global social and ecological crisis, such as stem from alienated 
and instrumentalist outlooks; pathological power-based mindsets; and a destructive "might is right" worldview that promotes violence, warfare, and ecological ruin. Animal rights probes to the core of the violent and domineering proclivities of Homo sapiens, such as are manifest throughout the entire span of its history. It works to overcome the schizophrenic, delusional, and arbitrary biases of humanism that relegate animals to resources for human benefit, reinforce ancient Western reductions of animals to human property, and, at best, advocate a welfarist position of "kindness to slaves" and "humane killing" while never questioning the contradictory nature of such phrases or challenging the legitimacy of slavery itself.

Victims of oppression cannot advance by oppressing and victimizing others. While the material constraints of poverty certainly conditions one's view of animals and nature, the conditions of scarcity and desperation must be alleviated as people must learn to view elephants (animals, in general) for what they really are—not "assets" and "harvestable resources," but rather complex persons with intrinsic value and basic rights.

The animal liberation movement insists not only that people change their views of one another, but also that they make a qualitative leap beyond humanism to rethink their relations to animals and the natural world. It argues that species boundaries are as arbitrary as those of race and sex and seeks to move the moral bar and boundaries of community from reason and language to sentience and subjectivity. By extending rights to sentient (not merely "rational") beings to protect them from human exploitation, by advancing deeper and more encompassing notions of moral equality, by developing a broader notion of community and citizenship, by forging a more profound and holistic mode of critical thinking, and by promoting changes in the human diet that have enormous positive consequences for human health, social justice, hunger, peace, and ecology, the animal liberation movement is a key catalyst of social change and moral progress and a necessary part of any revolution worth its name.

\section{Endnotes}

1. This paper would not have been possible without the inspiring influence and pioneering lead of Michele Pickover. The importance of her commitment to animal liberation and radical social change is manifest not only in her groundbreaking book, Animal Rights in South Africa-the first systematic application of animal rights theory and politics to South Africa-but also in her indefatigable activist achievements, such as in her work with Animal Rights Africa (http://www. animalrightsafrica.org/) . Moreover, thanks to her kind invitation to do a speaking tour throughout South Africa, I was able to experience the landscape, culture, and oppression of animals and people alike as concrete realities as well as to witness first hand how animal liberation is a global movement for change, one that can achieve its goals only by working within a broader struggle for total liberation.

2. As one among many ominous signs that the South African government is moving toward a pro-culling policy, in February 2007 Marthinus van Schalkwyk, the South African Minister of Environmental Affairs and Tourism, released a "Draft Norms and Standards for the Management of Elephants" report (http://www. info.gov.za/speeches/2007/07022811451001.htm) that advocated the use of culling as one of many responses to resolving the alleged threat elephants pose to ecological systems and the lives and property of human beings. In June 2007, at the 14th Conference of Parties of CITES in the Hague, numerous African elephant range states agreed on a nine year moratorium against ivory trade, but nonetheless allowed a one-year sell off of 60 tonnes of ivory stockpiles on the global trade market (see Richard Black, "Africa Cut Deal on Ivory Trade," BBC News, June 14, at: http://news.bbc.co.uk/1/hi/sci/ tech/6751853.stm). To help legitimate this move, the South African Department of Environmental Affairs claims that the funds will be channeled into conservation efforts, but animal rights critics argue that the lucrative profits in fact land in the pockets of state officials, that any marketization of ivory, however "controlled," encourages additional poaching, and that the move was intended to relieve the pressure of existing stockpiles in order to replenish them by slaughtering thousands more elephants; ssee "CITES 'Compromise' Signifies Disaster for Elephants" (http://www.animalrightsafrica. org/PR_14June07_CitesCompromise.php) and other reports on the Animal Rights Africa website at: http:// www.animalrightsafrica.org/AgonyOflvory.php).

3. Although I provide some general reasons why I think that animals, no different from us, have basic rights, I cannot here explore the many arguments and counterarguments of this complex moral controversy. For detailed reasoning in support of welcoming animals into our moral universe as equals, and no longer excluding them as inferiors, see Tom Regan, The Case for Animal Rights (Berkeley:University of California Press, 1983); Gary Francione, Introduction to Animal Rights: Your Child or Your Dog (Philadelphia:Temple University Press, 2000); and my own book, Animal Liberation and Moral Progress: The Struggle for Human Evolution (Lanham, MD:Rowman \& Littlefield, 
forthcoming, 2007). Some clarification of basis terms and assumptions, however, is in order.

A "right" is a moral and legal construct designed to secure for individuals freedom from exploitation, injury, or harm caused by other individuals or by institutions (such as corporations and government) in order to facilitate freedom to lead a pleasurable, autonomous, and meaningful life, where the boundaries of liberty are drawn at the point where one's choices and actions can cause actual or potential harm to liberty and sovereignty of other right-bearing members of society While they grant and protect individual and social freedoms, rights also come with responsibilities that impose duties and obligations of individuals to respect the autonomy, dignity, and freedom of others.

Individuals, corporations, and society as a whole vehemently reject the idea of animal rights because the uncompromising and nonutilitarian logic of rights (for animals as well as humans) demands that one treat right's bearers as ends-in-themselves not mere means to one's own purposes and gain. Rights define and help organize society as a community of equals.

The philosophy of animal rights build on the egalitarian conceptual framework of the human rights tradition that emerged in the 18th century, as it exposes and transcends the biases and arbitrary attempts to build rigid walls that isolate humans and nonhuman animals and thus banish animals from moral community. Deeply embedded within the religion, philosophy, science, and overall worldview of Western societies, sedimenting into "common sense" thinking that only mystics or madmen would dare challenge, the justification for human domination over animals, for over two thousand years, has been anchored in the ideology of "speciesism." According to the essentialist, hierarchical, and teleological outlook of speciesism, human beings regard themselves as superior to all other beings given their singular, unique nature that endows them with capacities for rational thought and language.

Rejecting the privileging of reason and language as arbitrary markers of rights and moral worth, the animal rights perspective grounds ethics in the property of sentience-in the capacity to feel, experience, and suffer, and not to reason, calculate, and symbolize-that determines the rightness or wrongness of an action and the boundaries of the moral community. Since animals experience pain and pleasure ways similar to us, and causing suffering or pain is an evil to be shunned, all sentient beings require basic rights-human constructs designed to regulate human behaviorthat protect their freedom from pain,, suffering, misery, torture, and violence death in order to enjoy the freedom to live as pleasure and free a live as possible. With the goal of dramatically broadening the moral community to protect the interests of not just one species but potentially millions of other species, animal rights requires that we treat sentient nonhuman beings in radically different terms: as "subjects of a life" (Regan) rather than objects or property. Unlike the comfortable, safe, and socially acceptable animal welfare view that promotes "kindness" to animals in order to reduce their suffering, enlarge their cages, and kill them more "humanely," the animal rights approach demands the total abolition of all forms of human exploitation of animals. In theory as well as practice, animal rights requires the elimination of rodeos, circuses, and zoos; of hunting, trapping, and fishing; of meat, dairy, egg, leather, and wool industries; and of animal product testing, research, and experimentation as well. Its goal is not bigger cages, but empty cages; not "humane treatment" of the slaves, but the emancipation of animals from slavery. Egalitarian and abolitionist in logic, animal rights is the moral and logical foundation for the political and practical goal of animal liberation.

4. I use the term "exploitation" of humans, slaves, blacks, or animals to describe the institutions and practices whereby dominant economic classes exploit the labor power of others for profit, gain, military development, and so on. I employ "domination" as a more general term concept that covers any and all forms of power one group exerts on others, such as emerges and evolves, is produced and reproduced, through the institutionalization of unequal degrees of force, violence, authority, privileges, property, and wealth or money. I broaden these and related concepts to apply them not only to human animals but also nonhuman animals, for the powerful reason that people do "dominate" animals in the sense of using superior (technological) power to control them, and they do "exploit" animals for their labor, body parts, bodily fluids, and virtually every part and molecule of their body and facet of behavior, making animals, in a real sense, the greatest body of "slaves" in the modern world, such that their labor power is crucial for economic growth and profits. Radical (eco)humanists such as Murray Bookchin impose and police strict boundaries on the semantic range of concept like "domination" and "liberation," to prevent, specifically, the conflation of the "social world" with the "natural world," the "first nature" of humans with the "second nature" of animals and the physical environment. This not only denies the fluid and continuous evolution of intelligence and subjectivity in nature (which contradicts Bookchin's natural and evolutionary outlook), trying to anchor its first/second nature dualism on some stable point amidst continual flux. It is rooted, in fact, in the most threadbare traditional speciesist notion-a favorite of Aristotle, Kant, Descartes, and so many otherssome concepts (1) function only in the context of a social world comprised of beings capable of rational thought, communication and language, and symbolic representation, and (2) only humans have such capacities.

5. See "Consuming Wild Life: The Illegal Exploitation of Wild Animals In South Africa, Zimbabwe and Zambia," 
March 2007 (compiled by Mike Cadman for Animal Rights Africa and Xwe African Wild Life), at: http:// www.animalrightsafrica.org/Archive/Consuming Wild_Life_290307_final.pdf.

6. For an illuminating treatment of the global business of trophy and canned hunting, see Matthew Scully, Dominion: The Power of Man, the Suffering of Animals, and the Call to Mercy (New York:St. Martin's Press, 2002), pp. 47-87. Scully describes how killing rare, huge, or endangered animals fetch hunters both money and status, along with, one presumes, a satisfying release of aggressive energy and galvanic boost to macho identity. Global hunting organizations such as the Safari Club elevate hunters to elite status if they bag enough big game, and the dream of every hunter who lives or travels to exotic places such as India or Africa is to kill over his or her hunting career an individual from the "Big Five": buffalo, elephant, rhino, lion, and leopard. The blatant commodification of killing wildlife is channeled through countless magazines and websites in order to lure tourists into expensive safari trips and "hunting packages."

7. "South Africa wants to hedge in hunting," May 3, 2006, iafrica.com: (http://cooltech.iafrica.com/ science/289452.htm).

8. See Kurt Schillinger, "Apartheid's Past, Democracy Collide Over Lion Sanctuary," The Boston Globe, February 9, 2003 (http://www.enkosini. com/2003.02.09\%20-\%20Apartheid's\%20Past $\% 20$ Democracy\%20Collide\%20Over\%20Lion \% 20 Sanctuary.htm.

9. With China, Japan, and other nations vying for position in ivory markets, the US is the world's leading buyer of illegal ivory; see the Care for the Wild International report at: "U.S. Exposed as Leading Ivory Market," at: http://www.careforthewild.com/files/ cwiusaivoryreport507final.pdf.

10. On the brutal nature of "structural adjustment" programs, see Jeremy Brecher et. al., Globalization from Below: The Power of Solidarity (Boston:South End Press, 2000), and Walden Bellow, "Structural Adjustment Programs: Success for Whom?) in The Case Against the Global Economy and For a Turn Toward the Local, Jerry Mander and Edward Goldsmith (eds.) (San Francisco:Sierra Club Books), pp. 285-293.

11. Cited in Pickover, Animal Rights in South Africa, p. 104.

12. Exemplifying the capitalist reduction of the entire earth to commodities and profit potential, consider the words of Martin Brooks, former employee of the SANP system and currently chairman of the World Conservation Union's African Rhino Specialists Group, for whom animals are nothing but harvestable resources to be stocked and replenished for financial gain: "'If you're going to kill an animal, it makes sense that it should have some conservation benefit. If it's the private sector that does that does that ... then that's an incentive for them to invest in black rhino populations for breeding, which is good. If the formal conservation agency allows hunting, or sells the surplus animals to private owners, that money goes back into the parks system" (cited in Nicole Itano, "Hunt a Rhino, Dave an Ecosystem?," The Christian Science Monitor, April 25, 2005, at: http://www.csmonitor.com/2005/0425/ p01s04-woaf.html).

13. For articles on the continuing poverty and plight of the South African people, see the online resources of Open Democracy at: http://www.opendemocracy.net/ editorial_tags/africa.

14. There are obvious dissimilarities in the analogy I draw between social and species apartheid, such as the fact that blacks Africans organized political groups and were not shot for sport, as elephants do not dig for gold or diamonds in mines But such superficial differences matter far less than the deeper continuities in the regimes of domination of human-over-human and human-over-animal, such as I attempt to describe later in this essay.

15. For an extended analysis of the hatred and contempt human beings frequently express toward animalseasily discerned in the paradigmatic picture of a mighty hunting warrior holding up the head of his or her kill, glowing in his superiority and as if he had a sexual release, see Jim Mason, An Unnatural Order: A Manifesto for Change (New York: Lantern Books, 2005).

16. Molotegi cited in the South African human education newsletter, The Latham Letter, Volume XXIV, Number 4, Fall 2003, online at: . http://www.latham. org/Issues/LL_03_FA.pdf.

17. "Apartheid and the Black Working Class: The Problem Defined," African National Congress website at: http://www.anc.org.za/ancdocs/history/congress/ sactu/organsta01.html.

18. Pickover, Animal Rights in South Africa, p. 78.

19. Pickover, Animal Rights in South Africa, p. 52.

20. For a more extended critique of Left humanism, see my essay, "Rethinking Revolution: Animal Liberation, Human Liberation, and the Future of the Left," The International Journal of Inclusive Democracy, Issue \#6, June 2006 (online at: http://www.inclusivedemocracy. org/journal/is6/Best_rethinking_revolution.htm).

21. Cited in "Africa-Ivory Wars," Foreign Correspondent, at: http://www.abc.net.au/foreign/ s221193.htm.

22. To provide an example of the objectifying, speciesist biases in everyday language, note that the common term "animal products" (e. g., meat, dairy, and eggs) reduces a whole, living, thinking and feeling being to fragmented and discrete things for human use. 
23. James Shikwati, "How to Protect People and Wildlife in Kenya," at: http://www.perc.org/perc.php?id=238.

24. On animal liberation and debates about sabotage and terrorism, see Steven Best and Anthony J. Nocella (eds.), Terrorists or Freedom Fighters? Reflections on the Liberation of Animals (New York:Lantern Books, 2004).

25. Shikwati, "How to Protect People and Wildlife in Kenya."

26. There will, of course, be cases of conflicting interests, where human and animal interests (according to human perceptions) clash (e.g., in the alleged need for humans to experience on animals in order to promote medical progress and human advance), but in most instances (such as sport hunting or meat consumption) there is no justification for exploiting animals. Justifications for animal experimentation too have been shown to be flawed on both empirical and moral grounds; see C. Ray Greek and Jean Swindle Greek, Sacred Cows and Golden Geese: The Human Costs of Experiments on Animals (Continuum:2002).

27. For a penetrating analysis of subsistence cultures in modern times and a critique of their rationale for killing animals, see Lisa Kemmerer, "Hunting Tradition: Treaties, Law, and Subsistence Killing," Journal of Critical Animal Studies, Volume II Issue 2, 2004, at: http://www.cala-online.org/Journal_Articles_ download/Issue_3/Hunting\%20Tradition.doc.

28. For claims that elephants and other animals and causing ecological damage and harming humans in numerous ways, see Suzanne Daley, "Ban on Sale of Ivory Is Eased to Help 3 African Nations," The New York Times, June 20, 1997 Rather than advocate killing elephants, some villagers and farmers have managed to protect their crops through ingenious nonviolent methods such as planting chili in the front rows of their crops.

29. For examples of speciesist conservationism that reject animal rights as an extremist discourse of privileged Westerners oblivious to the pressing needs of the poor, see the numerous articles posted on the International Wildlife Management Consortium site, at: http://www.iwmc.org/elephant/elephant.htm, and "Tiger Conservation: It's Time to Think Outside the Box," at: http://www.iwmc.org/PDF/IWMCtiger.pdf.

30. Dr. Bill Morrill, "Conservation and Elephant Hunting," at: http://www.iwmc.org/elephant/981127. htm.

31. Cited in Pickover, Animal Rights in South Africa, p. 109.

32. For brutal photographic evidence of the horrors of culling, see: http://www.animalrightsafrica.org/ Elephant_Gallery.php.
33. "The Challenge of the New Millennium," at: http:// assets.panda.org/downloads/wwfafint.pdf.

34. Ibid.

35. Delia Owens interviewed by Steve Curwood, transcript posted online at: http://www.loe.org/shows/ shows.htm?programID=93-P13-00005\#feature3.

36. For evidence of the growing South African "lion trophy" export industry, for example, see: http://www. animalrightsafrica.org/Archive/Hunting/Feb_07_ South_Africa_Lion_Trophy_Trade_Factsheet.pdf).

37. Pickover, Animal Rights in South Africa, p. 100.

38. Kurt Schillinger, "Apartheid's Past, Democracy Collide over Lion Sanctuary," http://www.enkosini. com/2003.02.09\%20-\%20Apartheid's\%20Past\%20 Democracy\%20Collide\%20Over\%20Lion \% 20 Sanctuary.htm.

39. See "The Elephant Lobby," Newsweek, September 8, 1997, pp. 60-61.

40. Thomas Malthus, An Essay on the Principle of Population (Oxford University Press, 1999).

41. On the growing dangers and scale of clashes provoked by resource scarcity, see Michael T. Klare, Resource Wars: The New Landscape of Global Conflict (New York:Holt Paperbacks, 2002).

42. For incisive (but not always fair or accurate) critiques of misanthropic and neo-Malthusian strains in contemporary environmental philosophies and movements such as Earth First! and deep ecology, see Murray Bookchin, Re-Enchanting Humanity: A Defense of the Human Spirit Against Anti-Humanism, Misanthropy, Mysticism, and Primitivism (London: Cassell, 1995).

\section{Whyte quoted in "A Numbers Game"}

44. Magome cited in Leon Marshall, "South Africa Weighs Killing 'Excess' Elephants in Parks," National Geographic News, November 5, 2004, online at: http://news.nationalgeographic.com/ news/2004/11/1105_041105_elephants.html.

45. "Elephant Ivory Trade Ban," online at: http://www. american.edu/ted/elephant.htm.

46. "Species Fact Sheet: African Elephant," World Wildlife Fund, at: http://assets.panda.org/downloads/ african_elephant_factsheet2007w.pdf.

47. See "Elephant Management in South Africa: The Need to Think BIG," at http://www.careforthewild.com/ files/Cullingreport05.pdf.

48. Kruger National Park "continues to suffer under a legacy of misguided management decisions, which 
range from the calculation of unsupported population limits for different animal species, large scale killing of all manner of those species-first predators, then ungulates and then predators again - the even provision of hundreds of waterpoints across all habitat types, rotational random burning policies, as well as ecological impatience, which fails to take long-term ecosystem dynamics into account. All these interventions worked against, rather than with, ecological processes of feedback and competition that regular populations and structure communities," ibid.

49. Ibid.

50. Ibid.

51. Pickover, Animal Rights in South Africa, p. 68.

52. Pickover, Animal Rights in South Africa, p. 69. The dynamic is similar to the United States, where hunters make the same ecological arguments for killing deer and other species. In many cases, deer overpopulation is the result of hunting, whereby hunters kill natural predators of deer such as coyotes and wolves. On the violent psychosis of hunters and the myths and fallacies of hunting, see "Hunting: The War on Wildlife" (http:// www.animalrightsafrica.org/Hunting.php) and "The Myth of Trophy Hunting as Conservation" (http://www. animalrightsafrica.org/TrophyHunting.php).

53. Consider, for example, the plight of the African rhinoceros population whose habitat is rapidly being consumed by human industry and out-of-control appetites: "Every landscape where the Asian rhino clings precariously to survival is suffering from the pressures of agricultural clearance, logging, encroachment by people in search of land, and commercial plantations for oil palm, wood pulp, coffee, rubber, cashew and cocoa" (Elizabeth Kemf and Nico van Strien, cited at http://www.awionline.org/pubs/quarterly/fallo2/rhino. htm). Other contributing causes include the canned hunting industry and the superstition-laden "alternative medicine" markets of Asia.

54. For one example of how local economies are better supported through conserving rather than poaching wildlife, see "Antipoaching patrols help wildlife more than local economic development," at: http://www. animalrightsafrica.org/Poaching_AntipoachingPatrols. php

55. "Where the Elephants Pay Their Way," The New York Times, April 12, 1997.

56. "Elephant Management in South Africa: The Need to Think BIG."

57. Ibid.

58. The WWF is involved in such a project, which I applaud, although I renounce their apology for hunting and assistance to communities involved in elephant hunting. In his article, "A Numbers Game: Managing Elephants in Southern Africa" (http://www. ens-newswire.com/ens/jul2006/2006-07-19-03.asp). Mark Schulman of the WWF International emphasizes the number of problems elephants cause humans and defends "sustainable wildlife hunting quotas" as set by the nation's Ministry of Environment and Tourism. Namibia WWF director intones, "You can do a lot with the money," and talks about how each elephant is worth $\$ 11,000$ which means a lot to commodities who can improved education, and so on" (I imagine the elephants mean a lot more to their herds). The report, "Namibia: Living in a Finite Environment (LIFE) Plus Project" (http://www.nric.net/tourism/ factsheets/Namibia.pdf), describes how "Namibia is working to improve the quality of life for rural peoples through sustainable natural resource management. Communities participating in LIFE have reaped substantial benefits from sale of thatching grass and crafts, tourist concessions, and revenues from trophy hunting." The sources of "revenue" are laudable if insensate things and objects like beads and pottery, but deplorable if sentient and complex beings-endangered species in this case-such that people profit from the slaughter of the innocent.

59. "Fate of South Africa's Elephants Hangs in the Balance," Justice for Animals and Xwe African Wild Life press release, October 11, 2004, at: http://www. justiceforanimals.co.za/news_elephants.html.

60. For a critique of overly optimistic views of "postapartheid Africa" that continues to be exploited by global market forces, see Julian Kunnie, Is Apartheid Really Dead? Pan-Africanist Working Class Cultural Critical Perspectives (Boulder, CO:Westview Press, 2000).

61. On the European impoverishment of Africa and other southern nations, see the classic study by Walter Rodney, How Europe Underdeveloped Africa (Washington, DC: Howard University Press, 1981). For a more recent critique of Western imperialism that builds on Rodney's analysis while updating it to address current global dynamics, see Patrick Bond, Looting Africa: The Economics of Exploitation (London and New York:Zed Books, 2006). In the post-9/11 political context suffused with neoliberal economics, fatuous neoconservative metanarratives of progress and visions of Empire by conquering the Middle East and other regions with bullets, bombs, and business deals, Bond documents how the situation in African continues to deteriorate in direct proportion to the promulgation of neoliberal and neoconservative ideologies and policies, the metastatic spread of transnational corporations that impose market systems and values and siphon resources to Europe and North America, the evertightening chokehold applied by international banking and financial systems that conquer through the strategy of loans (for the desperation they helped create in the first place) and debt (that oblige struggling nations to deliver their economies, states, and labor powers to the will of Western imperialism and market domination. Potentates such as Bush and Blair affect concern for the plight of Africans and promise to send significant sums 
of money and assistance, but the promises are mere props for political theater and the politics of deny and delay. The G8 has no intention of relinquishing Western domination over people, animals, and resources and meet annually not to craft the policies of global justice, peace, and democracy they extol to the world through the aid of compliant corporate media, but assemble instead (not always as one unified chorus) to consolidate the power of Western markets and militaries over the majority of nations in the world. Bob Geldof can organize Live Aid concerts every year and funnel paltry sums through the corrupt channels of bureaucracy that drop mere pennies into the hands of the poor, and Bono can speak truth to power and morality to markets until he can no longer sing, but his words fall on deaf ears. Oprah can underscore the weighty obligations wealthy Western nations have to alleviate the suffering, violence, poverty, disease, and death that is the ugly legacy of colonialism, but the global power elites will only push the throttle of extraction and development indifferent to the costs to people, animals, and the environment. Only revolutionary change on a mass scale has a chance of stopping the juggernaut of global capitalism, and transforming its nihilistic and destructive forces into life-affirming and constructive powers.

62. Leo Zeilig, "South Africa: Burning Anger in the Townships," Socialist Review, http://www. socialistreview.org.uk/article.php?articlenumber $=9682$.

63. See Murray Bookchin, The Ecology of Freedom: The Emergence and Dissolution of Hierarchy (Berkeley, CA: AK Press, 2005).

64. On the intricate interrelationship between cruelty to animals and violence toward other humans (such as manifests all-too-frequently in the actions of serial killers), see Frank R. Ascione and Phil Arkow, Child Abuse, Domestic Violence, and Animal Abuse: Linking the Circles of Compassion for Prevention and
Intervention (Lafayette, IN:Purdue University Press, 1999); Linda Merz Perez and Kathleen M. Heide, Animal Cruelty: Pathways to Violence Against People, (Lanham, MD:AltaMira Press, 2003); and Arnold Arluke, Just a Dog: Understanding Animal Cruelty and Ourselves (Philadelphia, PA: Temple University Press, 2006).

65. See Pickover, Animal Rights in South Africa, p. 131.

66. See "Human Zoo" at http://en.wikipedia.org/wiki/ Human_zoo.

67. Charles Patterson, The Eternal Treblinka: Our Treatment of Animals and the Holocaust (New York:Lantern Books, February 2202).

68. Charles Patterson interviewed by Richard Schwartz, at: http://www.powerfulbook.com/interview.html.

69. Marjorie Spiegel, The Dreaded Comparison: Human and Animal Slavery (New York:Mirror Books, 1996).

70. Felipe Fernandez Armesto, So You Think You're Human? A Brief History of Humankind (Oxford:Oxford University Press, 2004), p. 89.

71. Ibid..

72. Jeremy Rifkin, "Meat Makes the Rich Ill and the Poor Hungry," at: http://www.viva.org.uk/guides/ feedtheworld.htm. For further information on the social justice and hunger-alleviation implications of a plant-based diet, also see Rifkin, Beyond Beef, pp. 153-181; Francis Moore Lappe's classic study, Diet for a Small Planet (New York:Ballantine Books, 1991); and John Robbins' The Food Revolution: How Your Diet Can Help Save Your Life and Our World (Newburyport, MA:Conari Press, 2001).

\section{References}

Arluke, Arnold. 2006. Just a Dog: Understanding Animal Cruelty and Ourselves.

Armesto, Felipe Fernandez.2004. So You Think You're Human? A Brief History of Humankind.

Ascione, Frank R. Phil Arkow. 1999. Child Abuse, Domestic Violence, and Animal Abuse: Linking the Circles of Compassion for Prevention and Intervention.

Bellow, Walden. 1996. "Structural Adjustment Programs: Success for Whom?" in The Case Against the Global Economy and For a Turn Toward the Local, edited by Jerry Mander and Edward Goldsmith.

Best, Steven. 2007. Animal Liberation and Moral Progress: The Struggle for Human Evolution.

-----. 2006. "Rethinking Revolution: Animal Liberation, Human Liberation, and the Future of the Left." The International Journal of Inclusive Democracy 6:June 2006.
Best, Steven and Anthony J.Nocella, eds. 2004. Terrorists or Freedom Fighters? Reflections on the Liberation of Animals.

Bookchin, Murray. 2005. The Ecology of Freedom: The Emergence and Dissolution of Hierarchy. Berkeley, CA:AK Press.

-----. 1995. Re-Enchanting Humanity: A Defense of the Human Spirit Against Anti-Humanism.

Bond, Patrick. 2006. Looting Africa: The Economics of Exploitation.

Brecher, Jeremy et. al. 2000. Globalization from Below: The Power of Solidarity.

Daley, Suzanne. 1997. "Ban on Sale of Ivory Is Eased to Help 3 African Nations.” The New York Times, June 20, 1997.

Francione, Gary. 2000. Introduction to Animal Rights: Your Child or Your Dog.

Greek, Ray C. and Jean Swindle Greek. 2006. Sacred Cows and Golden Geese: The Human Costs of Experiments on Animal. 
Kemmerer, Lisa. 2004. "Hunting Tradition: Treaties, Law, and Subsistence Killing." Journal of Critical Animal Studies. II:2.

Klare, Michael T. 2002.Resource Wars: The New Landscape of Global Conflict.

Kunnie, Julian, Is Apartheid Really Dead? Pan-Africanist Working Class Cultural Critical Perspectives, 2000.

Lappe. Francis Moore. 1991 Diet for a Small Planet.

Mason, Jim. 2005. An Unnatural Order: A Manifesto for Change.

Patterson, Charles. 2002. The Eternal Treblinka: Our Treatment of Animals and the Holocaust.

Perez, Linda Merz and Kathleen M. Heide. 2003. Animal Cruelty: Pathways to Violence Against People.

Pickover, Michele. 2005. Animal Rights in South Africa.

Regan, Tom. 1983. The Case for Animal Rights.

Rifkin, Jeremy. 1992. Beyond Beef: The Rise and Fall of the Cattle Culture.

-----. "Meat Makes the Rich Ill and the Poor Hungry." (http:// www.viva.org.uk/guides/feedtheworld.htm).
Robbins, John. 2001. The Food Revolution: How Your Diet Can Help Save Your Life and Our World.

Rodney, Walter. 1981. How Europe Underdeveloped Africa.

Schulman, Mark. "A Numbers Game: Managing Elephants in Southern Africa." (http://www.ens-newswire.com/ens/ jul2006/2006-07-19-03.asp).

Scully, Matthew. 2002. Dominion: The Power of Man, the Suffering of Animals, and the Call to Mercy.

Shikwati, James. "How to Protect People and Wildlife in Kenya." (http://www.perc.org/perc.php?id=238).

Spiegel, Marjorie. 1996. The Dreaded Comparison: Human and Animal Slavery.

Zeilig, Leo. "South Africa: Burning Anger in the Townships." Socialist Review (http://www.socialistreview.org.uk/article. php?articlenumber $=9682$ ). 
